\title{
Factors for Self-Protective Behavior against Extreme Weather Events in the Philippines
}

\author{
Jana Lorena Werg ${ }^{1, *}$, Torsten Grothmann ${ }^{2}$, Michael Spies ${ }^{3}\left(\mathbb{C}\right.$ and Harald A. Mieg ${ }^{1}$ \\ 1 Department of Geography, Humboldt-University Berlin, 10117 Berlin, Germany; harald.mieg@hu-berlin.de \\ 2 Ecological Economics Group, Carl von Ossietzky University of Oldenburg, 26129 Oldenburg, Germany; \\ torsten.grothmann@uni-oldenburg.de \\ 3 Centre for Econics and Ecosystem Management, Eberswalde University for Sustainable Development, \\ 16225 Eberswalde, Germany; michael.spies@hnee.de \\ * Correspondence: jana.werg@hu-berlin.de; Tel.: +49-30-234-686-57
}

Received: 12 June 2020; Accepted: 23 July 2020; Published: 27 July 2020

\begin{abstract}
We report the results on factors for self-protective behavior against weather extremes such as extreme heat events, drought, and heavy precipitation. Our research draws on the Model of Private Proactive Adaptation to Climate Change (MPPACC). We developed a survey instrument incorporating the main aspects of the MPPACC and other factors from related research work that are assumed to explain why some people show self-protective behavior while others do not. The interview survey was conducted with a non-random sample of 210 respondents from three Philippine cities, namely Baguio, Dagupan, and Tuguegarao. The results reveal the importance of adaptation appraisal, including the perceived feasibility of self-protective measures, the perceived adaptation knowledge, and, with limitations, the perception of actions taken by neighbors or friends. We also show that perceptions of past weather trends are closely linked to risk perception but are only partly corroborated by weather station data. Implications for fostering self-protective behavior are making use of time windows right after an extreme weather event and focusing on enhancing adaptation appraisal.
\end{abstract}

Keywords: natural hazards; climate change; perception; self-protective measures; adaptation

\section{Introduction}

The Philippines belongs to the countries most affected by impacts of weather-related loss events [1]. Several tropical cyclones cross the country every year-triggering floods and landslides. The Philippines has abundant rainfall, yet some areas are semi-arid and prone to drought. Due to climate change, a global increase in weather-related extremes such as droughts, heat waves, and torrential rains is likely [2]. Furthermore, in Southeast Asia, increases in precipitation extremes related to the monsoon are very likely [3].

A high dependency on agriculture and natural resources, a high population growth rate, deforestation, overuse of natural resources, pollution and waste accumulation, and rapid urbanization and industrialization aggravate people's vulnerability to the impacts of climate change [4]. These factors can turn events that might only be moderately hazardous into major disasters-as illustrated by what happened during several disastrous floods that have occurred over recent years; high amounts of rainfall combined with waste clogging the waterways, resulting in floods and causing vast damages and loss of lives [4]. Flooding due to heavy rainfalls is one of the main weather-related risks-often in combination with heavy storms. However, droughts and heat waves also pose risks to crops and people's general health. In the Philippines, droughts affect a higher number of people than any other natural disaster-while not being as deadly as other disasters [5]. 
Self-protective measures-measures that individuals can carry out on their own to reduce damage-can highly contribute to protecting lives, crops, and property from the harmful effects caused by strong rain, drought or high temperatures [6]. These measures include precautionary measures as well as immediate behavior as a reaction to an occurring natural disaster. Motivating people to undertake self-protective measures is an important component in averting harm caused by such weather extremes. Hence, governmental and non-governmental institutions can not only implement measures such as dikes, tree planting or waste management, but can also support campaigns and organizations aiming at increasing people's understanding of the necessity to conduct household-level measures and increasing their motivation in this regard [7,8].

The main aim of this study is to better understand the level of, and explanatory factors for, self-protective behavior of (potentially vulnerable) private households against the impacts of extreme weather events in the Philippines. Our approach was exploratory rather than theory testing. We assumed elements of the Model of Private Proactive Adaptation to Climate Change (MPPACC) might be applicable to the Philippine context, yet the sample size and the lack of cultural validation of the MPPACC as well as the questionnaire reveal its rather exploratory nature.

It has long been established that human behavior is only partly influenced by rationality. The Theory of Planned Behavior (TPB) has been one of the most influential theories to explain human behavior in environmental psychology, including people's beliefs about the outcome of their actions, how they value that outcome, and their own self-efficacy [9]. It has also been applied to understanding disaster preparedness in individuals $[10,11]$. Additionally, different models have been developed to specifically explain why some people undertake self-protective measures against natural hazards while others do not, such as the Person-relative-to-event (PrE) model [12] or the Protective Action Decision Model (PADM) [13]. The PrE model proposes that individuals are more likely to engage in more problem-focused coping activities when they assess their resources sufficient, relative to the magnitude of a threat [12]. The PADM includes the aspect of individuals' processing of information and identifies three 'pre-decision processes' (reception, attention, comprehension) critical to all further processing, and ultimately, individual behavior [13]. Keeping in mind the mentioned theories, the theoretical reasoning behind our research is based on the Model of Private Proactive Adaptation to Climate Change (MPPACC; see Figure 1) focusing on cognitive processes [14]. The model was originally developed for explaining proactive private adaptation behavior (i.e., behavior before the event) regarding climate change (including adaptation to increasing extreme weather events). In our research, we apply the model to both self-protective measures before and during three kinds of extreme weather events (heat, drought, heavy precipitation), all assumed to increase in frequency and/or intensity due to climate change [2]. The MPPACC is strongly based on the Protection Motivation Theory (PMT) $[15,16]$. The PMT includes five central constructs regarding self-protective behavior: (i) perceived future probability and (ii) perceived severity of a threatening event-resulting in 'threat appraisal', (iii) the perceived efficacy of the self-protective behavior in question, (iv) the perceived self-efficacy (i.e., perceived ability to conduct the behavior), and (v) perceived costs of conducting the behavior-resulting in 'coping appraisal' [16]. The MPPACC describes the cognitive process people undergo when facing risks from climate change and includes mainly psychological factors that are to explain and predict individual climate adaptation intentions and behavior. The two main explanatory factors in this model are climate change risk appraisal (based on PMT's 'threat appraisal') and adaptation appraisal (based on PMT's 'coping appraisal') (see Figure 1). People appraise their personal risk of being affected by climate change (i.e., (a) the perceived probability of being exposed to impacts of climate change and (b) the perceived personal severity of these impacts) and their ability to adapt to it (i.e., (a) perceived adaptation efficacy, or the belief in self-protective behavior to be actually effective in protecting oneself or others, (b) perceived self-efficacy or the person's perceived ability to actually perform the self-protective behavior, and (c) perceived adaptation costs as the assumed costs of taking the self-protective behavior such as money, time, effort). When risk appraisal is low, individuals refrain from adaptation action. If high risk appraisal coincides with high adaptation 
appraisal, adaptive responses are triggered. If high risk appraisal meets low adaptation appraisal, people turn to avoidant maladaptation, e.g., fatalism or denial of the risk. Avoidant maladaptation mitigates the negative emotional consequences of feeling helpless when faced with a perceived risk. Further variables included in the MPPACC are the objective adaptive capacity (e.g., resources like time, money, knowledge) that enable or impede performing the intended self-protective behavior. Cognitive biases can irrationally affect the perceived adaptive capacity, leading to misjudgments of the risks or the adaptation options. Having experienced the risk already in the past increases the perceived risk, whereas reliance on public adaptation reduces it.

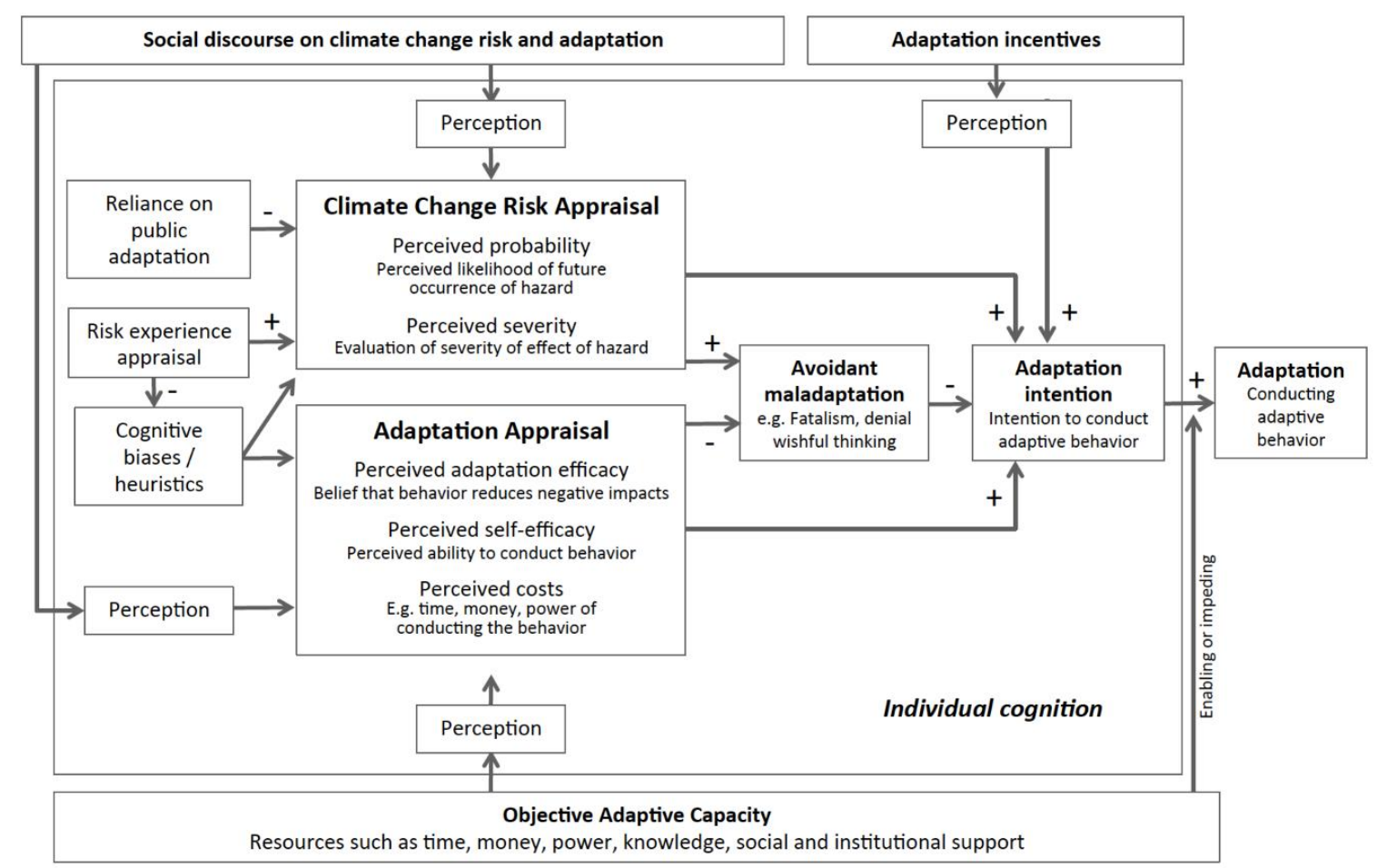

Figure 1. Model of private proactive adaptation to climate change, MPPACC (own illustration based on Grothmann and Patt, p. 204 [14]).

There are studies based directly on the MPPACC $[17,18]$, while other studies only take into account single components of the model $[19,20]$. Factors for which a positive relation with the intention to adapt could be found, were (a) risk appraisal, i.e., perceived climate risk [17], (b) adaptation appraisal, i.e., households' assessments of their own abilities to adapt $[17,18,20]$, and (c) objective adaptive capacity such as knowledge [19]. In a meta-analysis of 37 studies to explain individual adaptation to flood risks, Bamberg et al. [21] found, on average, a low predictive power (15\% explained variance) of an extended Protection Motivation Theory model, which adds trust in public protection (identical with reliance on public adaptation in MPPACC), negative flood-related emotions, and past flood experiences (identical with risk experience appraisal in MPPACC) to threat and coping appraisal. On the other hand, Grothmann and Reusswig [20] found explained variances in individual adaptation to flood risks for an extended PMT model of up to $45 \%$. The extended model included, in addition to threat appraisal and coping appraisal, the appraisal of past flood experiences (identical with risk experience appraisal in MPPACC), reliance on public flood protection, and avoidant responses like fatalism and denial. Additionally, a recent study by Valkengoed and Steg [22] conducting a series of meta-analyses using data from 106 studies on self-protective behavior from flooding, hurricanes, wildfire, heatwaves, droughts, and climate change came to the conclusion that Protection Motivation Theory may be a relevant theory to explain such behavior, as its key components were all important predictors of (intentions to engage in) self-protective behavior in their meta-analyses. Although these meta-analyses 
were not available in the year of the design of this study (2010), various studies then available indicated PMT's explanatory power for self-protective behavior regarding natural hazards [20]. As noted before, the MPPACC was developed based on the PMT and we, therefore, used it as the starting point of our study design.

Other factors apart from those covered by the MPPACC, for which a relation to self-protective behavior could be found, are: (a) the existence of role models [23-25]; (b) perceived social norms [26]; (c) knowledge of protective measures, with findings being inconclusive due to people possibly being overconfident regarding the invulnerability of their household [25,27]; (d) trust in (official) information sources, with findings again being inconclusive since trust e.g., in local authorities might also lead to a reduced feeling of risk, which, in turn, can be a barrier to private protection measures [22,28-30]; trust in information sources (mass media, social in-group and out-group) [31]; (e) livelihood dependent on nature [32]; as shown by Valkengoed and Steg [22], (f) place attachment; (g) climate change belief; (h) perceived responsibility; (i) negative affect; (j) descriptive norms; (k) injunctive norms (both norms closely related to the perceived social norms already mentioned above). For a more comprehensive overview of factors that show correlations with self-protective behavior regarding climate change and natural hazards, see Valkengoed and Steg [22] and Werg et al. [33].

We assigned the variables included in this study to the two main explanatory factors of the MPPACC, i.e., risk appraisal and adaptation appraisal (see Figure 1), including variables from the MPPACC [14] as well as additional variables such as "livelihood dependent on nature" and "perceived private responsibility" for conducting self-protective behavior. We consider the assigned variables as being relevant to the two explanatory factors (see Table 1) in terms of potentially raising or lowering risk (adaptation) appraisal, but do not combine them in a summative value for risk appraisal or adaptation appraisal in order to be able to detect the individual influences of the various variables on self-protective behavior. The reasoning behind the assignment of the different variables to the two main explanatory factors was to provide some categorization of the variables in terms of their relation to the risk or the options for self-protective behavior.

Unlike the MPPACC, where knowledge is assumed to be relevant to objective adaptive capacity, we assumed that it makes a difference whether people feel knowledgeable about weather changes (being relevant to risk appraisal) or about actual self-protective measures (being relevant to adaptation appraisal). In addition, since research has so far produced inconclusive results regarding the role of knowledge and whether it raises or lowers risk appraisal [34,35] (also see Table 1), we felt that this differentiation might offer a clearer picture. We integrated perceived self-efficacy (belief that oneself can conduct a self-protective behavior) and perceived adaptation efficacy (belief that such self-protective behavior is effective in preventing damage) from the MPPACC in the variable perceived feasibility of self-protective measures (belief that self-protection is possible), reducing complexity, and thereby following suggestions from the local project partners. Additionally, we assumed people who get their information from several information sources they actually trust would be more likely to act upon the information they get $[36,37]$ (see Table 1).

A further aim of this study is to understand the accuracy of the risk experience appraisal, which is considered an influential factor for risk appraisal in the MPPACC [11]. Perceptions of changing weather trends in the past are linked to assumptions regarding the likelihood of weather events in the future-which, in turn, is important with regard to risk perception: How likely is an event? To what extent will it affect me? However, perceptions of trends in past weather are not necessarily accurate. For example, a study in Zimbabwe has shown that farmers' perceptions of climate change and variability differ from climatological evidence [38]. To understand the accuracy of the risk experience appraisal of private households in the Philippines, we studied the degree to which perceptions of trends in the frequency of natural hazards can be substantiated by climate records. 
Table 1. Variables included in the survey. Assumed direction of influence indicated in brackets.

\begin{tabular}{|c|c|c|c|}
\hline Variable & Operationalization & Answer Categories ${ }^{1}$ & References \\
\hline $\begin{array}{l}\text { R0. Perceived past } \\
\text { weather trends }\end{array}$ & $\begin{array}{c}\text { As far as you can } \\
\text { remember-looking at the last } \\
\text { couple of years or even } \\
\text { decades-has there been a change } \\
\text { in the frequency of periods of hot } \\
\text { days (droughts/strong rains) } \\
\text { occurring in your city? }\end{array}$ & $\begin{array}{l}\text { Less often than before, as } \\
\text { often as usual, more often } \\
\text { than before }\end{array}$ & [38] \\
\hline \multicolumn{4}{|c|}{ Factors relevant to risk appraisal (R.1-R.6) (Broader understanding than in MPPACC) } \\
\hline $\begin{array}{l}\text { R1. Perceived future } \\
\text { probability }(+)\end{array}$ & $\begin{array}{c}\text { In the future, in your opinion, how } \\
\text { will the frequency of periods of } \\
\text { hot days/droughts/strong rains } \\
\text { change in your city? }\end{array}$ & $\begin{array}{l}\text { Will become less often; } \\
\text { no change; will become } \\
\text { more often }\end{array}$ & {$[17,39,40]$} \\
\hline R2. Perceived severity (+) & $\begin{array}{l}\text { All in all, how good or bad are } \\
\text { periods of hot } \\
\text { days/droughts/strong rains } \\
\text { for you? }\end{array}$ & $\begin{array}{l}\text { Bad; neither good } \\
\text { nor bad, good }\end{array}$ & [39-41] \\
\hline $\begin{array}{l}\text { R3. Reliance on public } \\
\text { adaptation }(-)\end{array}$ & $\begin{array}{l}\text { I think the government will take } \\
\text { care that impacts of weather won't } \\
\text { affect me. }\end{array}$ & $\begin{array}{l}\text { Don't agree; more or less } \\
\text { agree; agree strongly }\end{array}$ & [20] \\
\hline $\begin{array}{l}\text { R4. Perceived risk } \\
\text { knowledge }(+)\end{array}$ & $\begin{array}{l}\text { I feel well informed about weather } \\
\text { changes in my city over several } \\
\text { years. }\end{array}$ & $\begin{array}{l}\text { Don't agree; more or less } \\
\text { agree; agree strongly }\end{array}$ & [34] \\
\hline $\begin{array}{l}\text { R5. Effects of } \\
\text { weather events }\end{array}$ & $\begin{array}{l}\text { What effects do periods of hot } \\
\text { days/droughts/strong rains have } \\
\text { on your personal life? }\end{array}$ & Open answers & \\
\hline $\begin{array}{l}\text { R6. Livelihood } \\
\text { dependency on } \\
\text { environment (+) }\end{array}$ & $\begin{array}{l}\text { Is your livelihood dependent on } \\
\text { the environment? }\end{array}$ & $\begin{array}{l}\text { Not at all; to some extent; } \\
\text { very much }\end{array}$ & {$[32,42]$} \\
\hline \multicolumn{4}{|c|}{ Factors relevant to adaptation appraisal (A1-A7) (Broader understanding than in MPPACC) } \\
\hline $\begin{array}{l}\text { A1. Perceived feasibility of } \\
\text { self-protective } \\
\text { measures }(+)\end{array}$ & $\begin{array}{l}\text { How possible is it for you to } \\
\text { protect your house, yourself, your } \\
\text { income from negative effects? }\end{array}$ & $\begin{array}{l}\text { Not at all possible; possible } \\
\text { to some extent; very possible }\end{array}$ & {$[17,18,20]$} \\
\hline $\begin{array}{l}\text { A2. Perceived adaptation } \\
\text { knowledge }(+)\end{array}$ & $\begin{array}{l}\text { I feel well informed about } \\
\text { strategies or measures to deal with } \\
\text { weather changes in my city. }\end{array}$ & $\begin{array}{l}\text { Don't agree; more or less } \\
\text { agree; agree strongly }\end{array}$ & {$[19,25,27]$} \\
\hline $\begin{array}{l}\text { A3. Perceived barriers to } \\
\text { self-protective behavior (-) }\end{array}$ & $\begin{array}{l}\text { What makes it difficult for you to } \\
\text { protect yourself? }\end{array}$ & Open answers & \\
\hline $\begin{array}{c}\text { A4. Perceived } \\
\text { self-protective measures by } \\
\text { others }(+)\end{array}$ & $\begin{array}{l}\text { People I know have already taken } \\
\text { measures to deal with } \\
\text { weather events. }\end{array}$ & $\begin{array}{l}\text { Don't agree; more or less } \\
\text { agree; agree strongly }\end{array}$ & [23-26] \\
\hline $\begin{array}{l}\text { A5. Perceived private } \\
\text { responsibility for } \\
\text { protective measures (+) }\end{array}$ & $\begin{array}{l}\text { All citizens are individually } \\
\text { responsible for preventing } \\
\text { damages due to weather events in } \\
\text { their household. }\end{array}$ & $\begin{array}{l}\text { Don't agree; more or less } \\
\text { agree; agree strongly }\end{array}$ & {$[12,43]$} \\
\hline $\begin{array}{l}\text { A6. Information from } \\
\text { different sources on } \\
\text { weather changes and } \\
\text { protective measures }(+)\end{array}$ & $\begin{array}{l}\text { How much information } \\
\text { concerning weather changes } \\
\text { (measures to protect yourself from } \\
\text { weather events) do you get from } \\
\text { different information sources } \\
\text { (TV, newspaper, radio, scientific } \\
\text { institutions, NGOs, government }{ }^{2} \text { ) }\end{array}$ & $\begin{array}{l}\text { None; some; very much } \\
\text { (separate tick for each } \\
\text { information source) }\end{array}$ & [36] \\
\hline $\begin{array}{l}\text { A7. Trust in different } \\
\text { information sources }(+)\end{array}$ & $\begin{array}{l}\text { How much do you trust the } \\
\text { information sources? }\end{array}$ & $\begin{array}{l}\text { None; some; very much } \\
\text { (separate tick for } \\
\text { each source) }\end{array}$ & {$[22,28-31,37]$} \\
\hline
\end{tabular}


Table 1. Cont.

\begin{tabular}{|c|c|c|c|}
\hline Variable & Operationalization & Answer Categories ${ }^{1}$ & References \\
\hline \multicolumn{4}{|c|}{ Socio-demographic factors (S1-S4) } \\
\hline S1. Age (-) & How old are you? & Count & {$[44]$} \\
\hline S2. Gender & Are you female or male? & Female/male & {$[44]$} \\
\hline S3. Educational level $(+)$ & $\begin{array}{c}\text { What is your highest } \\
\text { educational qualification? }\end{array}$ & $\begin{array}{l}\text { No formal; prim; second; } \\
\text { voc; tert; B.A. or higher }\end{array}$ & {$[45,46]$} \\
\hline $\begin{array}{l}\text { S4. Household/economic } \\
\text { status }(+)\end{array}$ & What do you use for cooking? & $\begin{array}{l}\text { Coal/wood; gas or } \\
\text { electricity; other }\end{array}$ & {$[44,47]$} \\
\hline \multicolumn{4}{|c|}{ Dependent Variable: Self-Protective Measures (D.1-D.2) } \\
\hline $\begin{array}{c}\text { D1. Self-protective } \\
\text { behavior (any measures) }\end{array}$ & $\begin{array}{l}\text { Have you undertaken any } \\
\text { measures to protect yourself from } \\
\text { negative effects of weather events? }\end{array}$ & Yes; no & \\
\hline $\begin{array}{l}\text { D2. Measures by } \\
\text { weather extreme }\end{array}$ & $\begin{array}{l}\rightarrow \text { If yes, please explain shortly } \\
\text { which measures } \\
\text { Heat D2-H; Drought D2-D; } \\
\text { Rain D2-R }\end{array}$ & $\begin{array}{c}\text { Open answers, sorted by } \\
\text { weather event }\end{array}$ & \\
\hline
\end{tabular}

${ }^{1}$ Coded 1 (less often; bad; none; do not agree; not at all possible), 2, 3 (accordingly); "Internet" was also listed but excluded from analysis because only very few respondents claimed it as a source of information.

\section{Methods}

\subsection{Description of the Study Region}

The study was conducted in three cities on the Philippine Island of Luzon, namely Baguio, Dagupan, and Tuguegarao (see Figure 2). Criteria for choosing the cities under study were different climatic and geographical conditions as well as access to local resources through the project partners involved from the ICLEI Southeast Asia Secretariat. To allow a better understanding of the cities under study, we provide some basic information regarding their geography, climate, and trends in mean temperature and precipitation (see Table 2). Trends were calculated based on data from the Philippine Atmospheric, Geophysical and Astronomical Services Administration (PAGASA). Additionally, representatives from the administrations of the three cities provided qualitative information on climate change-related risks during a stakeholder workshop in 2012 [48].

\subsection{Sample and Survey Method}

We conducted standardized interviews with citizens of the three cities in order to assess the relation between factors assumed to influence the likelihood of people taking self-protective measures (independent variables) and the actual implementation of measures (dependent variables, see Table 1). A total of $n=210$ interviews were completed in 2011, with researchers from the Southeast Asia Secretariat of Local Governments for Sustainability (ICLEI SEAS) approaching potential respondents on the street and conducting face-to-face interviews on the spot.

Interviewers were instructed to include people who are considered particularly vulnerable to the impacts of extreme weather events, such as the poor, females, or the elderly [33]. This approach resulted in a non-random, biased sample, reflected in an overrepresentation of females of $60 \%$ as against 40\% males, a high mean age of 50 (vs. 23 in the Philippine population in 2010) with an age range of 18-86, and an overall unemployment rate of $6 \%$ (vs. 3.59\% in 2011 for the Philippines) [49]. The survey instrument (questionnaire) was used in English and, if respondents' English was not sufficient for them to fully understand a question, translated into local dialect (see Table S1 in the Supplementary Material for complete questionnaire). 


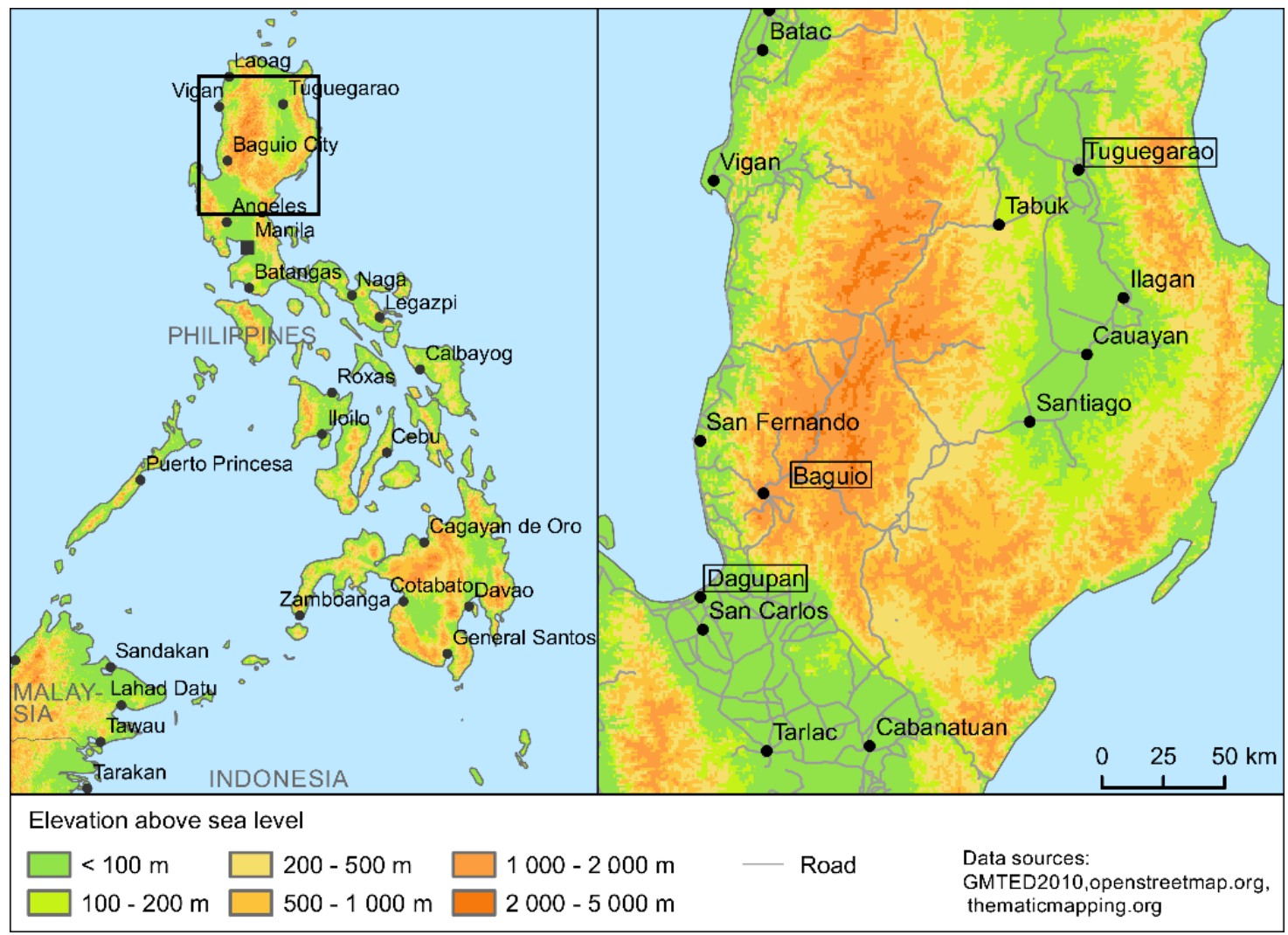

Figure 2. Northern Island of Luzon with the three cities under study: Baguio, Dagupan, and Tuguegarao.

Table 2. Cities under study (data as of 2018). Reported trends based on PAGASA data 1970-2010.

\begin{tabular}{cccc}
\hline & Baguio & Dagupan & Tuguegarao \\
\hline Province & Benguet & Pangasinan & Cagayan \\
\hline Population & 300,000 & 160,000 & 130,000 \\
\hline Geography & $\begin{array}{c}1500 \text { masl in the } \\
\text { mountains of Luzon }\end{array}$ & $\begin{array}{c}\text { Coastal, West coast of } \\
\text { Luzon, few masl }\end{array}$ & $\begin{array}{c}\text { 20-30 masl, in low plain, } \\
\text { borders river Cagayan }\end{array}$ \\
\hline Climate & $\begin{array}{c}\text { Subtropical highland } \\
\text { climate (mild) }\end{array}$ & Tropical monsoon climate & Tropical monsoon climate \\
\hline $\begin{array}{c}\text { Mean annual } \\
\text { precipitation }\end{array}$ & $3900 \mathrm{~mm}$ & $2400 \mathrm{~mm}$ & 1750 mm \\
\hline $\begin{array}{c}\text { Mean annual } \\
\text { temperature }\end{array}$ & $19.5^{\circ} \mathrm{C}$ & $27.7^{\circ} \mathrm{C}$ & $27.1^{\circ} \mathrm{C}$ \\
\hline $\begin{array}{c}\text { Trends in mean } \\
\text { temperature }\end{array}$ & $\begin{array}{c}\text { Accumulative increase of } \\
\text { ca. } 0.23^{\circ} \mathrm{C} \text { (not significant) }\end{array}$ & $\begin{array}{c}\text { Slight decline of } 0.12 ~ \\
\text { (not significant) }\end{array}$ \\
\hline $\begin{array}{c}\text { Trends in mean } \\
\text { precipitation }\end{array}$ & $\begin{array}{c}\text { Vast interannual variations, } \\
\text { no significant trend }\end{array}$ & $\begin{array}{c}\text { Vast interannual variations, } \\
\text { no significant trend }\end{array}$ & $\begin{array}{c}\text { Vast interannual variations, } \\
\text { no significant trend }\end{array}$ \\
\hline $\begin{array}{c}\text { Assumed main } \\
\text { weather-related risks }\end{array}$ & $\begin{array}{c}\text { Flooding due to strong } \\
\text { rain; rainfall } \\
\text { triggered landslides }\end{array}$ & $\begin{array}{c}\text { Flooding due to strong rain } \\
\text { and coastal storm surges }\end{array}$ & $\begin{array}{c}\text { Flooding due to strong } \\
\text { rain in the river basin; heat } \\
\text { and drought }\end{array}$ \\
\hline
\end{tabular}

${ }^{1}$ The most remarkable perturbation of the change in mean annual temperature is associated with eruptions of Mt.

Pinatubo; ${ }^{2}$ As assessed during an expert workshop within the Asian Cities Adapt Project [48].

Table 1 shows the independent variables that we assumed to have had an influence on whether people had taken self-protective measures or not (R1-R6; A1-A7; S1-S4) with their assumed direction of influence $(+/-)$, as well as the dependent variables (D1, D2) and their operationalization in the questionnaire. All items were developed in an iterative communication process within a team of researchers from the Potsdam Institute for Climate Impact Research and local administrative officers 
and practitioners from the three cities under study. To guarantee cross-cultural comprehensibility of the items, there was an extensive process of discussion and agreement with the local research partners regarding the comprehensibility of the questions. It was assumed crucial to keep the interview questions as simple as possible, keeping in mind the interview situation (on the street) and the low educational level of many of the respondents.

\subsection{Steps of Data Analysis}

In order to understand the degree to which the perception of trends in the frequency of extreme rainfall, droughts, and heat events by the respondents of our sample (R0) can be substantiated by climate records, we analyzed and plotted weather station data for the years 1970-2010 and 1990-2010, to provide information on long-term trends (1970-2010), while at the same time, including information on trends in the time period that is presumably more relevant to people's perception (1990-2010).

To obtain a better understanding of what it means when respondents stated they undertook self-protective measures, we took a closer look at the qualitative answers to the respective question. Respondents were asked if they had already undertaken measures to protect themselves from the impacts of extreme weather events (D1). If so, they were asked to specify the measures taken (D2). However, quite a few respondents answered "yes" without specifying any measures. Others answered "no" but still went on to name such measures. Since we were interested in the question if people really undertook any measure, we recoded the data, creating a variable that indicates if people actually reported any measures. The change in coding for the question "Have you already taken measures to protect yourself from extreme weather events?" (D1) comparing before and (after) was as follows (answers in \%): Yes: 78.6 (69); No: 16.7 (20.5); Missing 4.8 (10.5) $n=210$. When subjects stated "yes" without mentioning any measures even though they were requested to do so, we found the answer too inconclusive and recoded those answers as "missing". That is why the amount of missing values increased through recoding.

Additionally, we took some analytical steps to find out whether the nature of the measures (i.e., reactive rather than proactive) and whether people took measures regarding just one or several weather events made a difference to the relation between the explaining variables and the dependent variable. Following Mayring's procedure of a structuring content analysis [50,51], we analyzed the answers to the open question of which self-protective measures people had undertaken. By doing so, we created four further dependent variables for different weather events: Self-protective measures against heat (D2-H), drought (D2-D), heavy rain (D2-R), and all weather extremes (D2-comb), the letter being a combined additive variable for measures regarding all events. We also classified the different measures people undertook into (a) reactive behavior (e.g., staying inside), (b) proactive behavior (e.g., stocking emergency supplies), (c) preventing damage (e.g., enforcing house structure), and (d) adaptation. We did so because the qualitative answers showed that many measures mentioned are of a rather reactive nature (e.g., stay indoors in case of heavy rain), while others mentioned measures that are "truly" precautionary, such as building nipa huts for shade (heat and potentially rain when elevated), finding alternative livelihood projects (drought), or elevating the floor of their home (rain). There was a big difference regarding the frequency of measures of proactive nature (adding proactive, preventive, and adaptive measures), ranging from $54.2 \%$ regarding measures related to heavy rain events in Baguio to just 7\% (4.2\%) regarding heat- (drought-) related measures in Dagupan. We included those types of behavior as different values (on a scale ranging from 1 for no behavior to 5 for adaptation) as well as using the different types of behavior as dependent variables in later regression analyses further exploring the data. Since there were no significant differences in the results compared to the dependent variable D1, for all further analyses and reporting, we used the coding that corresponds with the original item, i.e., answer categories "yes" and "no" in the questionnaire (D1). However, we included the different dependent variables for D2 (heat, drought, rain).

We conducted a theory-based factor analysis, grouping the variables R1 (perceived future probability) and R2 (perceived severity) to the factor "risk perception" (additive with values between 6 
and 18), and grouping the variables A6 (amount of information on weather changes and measures) and A7 (trust in information sources) to the factor "Information \& Trust" (additive with variables between 18-54) (see Supplementary Material on factor analyses for more detail).

Correlation analyses as well as simple binary regression analyses for each variable were conducted. Based on those results, we then calculated hierarchical logistic regressions for the cities of Dagupan and Tuguegarao, each with taking all independent variables that showed statistically significant Nagelkerke's $R^{2}$ in the first step of analysis into the analysis, namely: (a) Risk perception $(R 1+R 2)$; (b) Perceived risk knowledge (R4); (c) Perceived feasibility (A1); (d) Perceived adaptation knowledge (A2), (e) Perceived self-protective measures by others (A4), and (f) Trust in/amount of information from different information sources (A6/A7); (g) Educational level (S3); (h) Household status (S4). The variables were entered block-wise (block 1: Risk appraisal variables, block 2: Adaptation appraisal variables, block 3: Socio-demographic variables), with forward selection for each block. Regression analyses were calculated separately for the different weather extremes (heat, drought, rain) as well as for the dependent variable (D1), including all weather events for self-protective measures to any of the three weather extremes for the overall sample as well as the individual cities (see Section 3.3). The only correlation higher than 0.70 was between the variables "perceived risk knowledge" (R4) and "perceived adaptation knowledge" (A2) for Tuguegarao. As to avoid problems associated with multicollinearity [52], regression analysis was conducted separately (including only either of the two variables) and with both variables. In none of the regression models, "perceived risk knowledge" (R4) or "perceived adaptation knowledge" (A2) were included due to a lack of significantly explaining any additional variance. We did not calculate hierarchical regressions for Baguio due to a lack of variables showing significant correlations with self-protective behavior.

\section{Results}

\subsection{Reported Self-Protective Behavior}

Table 3 shows the effects of extreme weather events people mentioned (R5), the percentage of respondents that undertook measures (D1), the self-protective measures mentioned (D2), and perceived barriers to self-protective behavior (A3).

\subsection{Accuracy of Perceived Trends in Occurrence of Extreme Weather Events}

In the following, we describe the results showing the degree to which the perception of trends in the frequency of extreme rainfall, droughts, and heat events by the respondents of our sample (R0) can be substantiated by climate records. We chose to depict the weather trends for events above the 90th percentile-assuming that in people's perception, such events stick in their memory as "extreme" events (rather than just events above the 99th percentile).

Heat waves/hot days: We define a heat wave day as a day within a period of five or more consecutive days on which the maximum daily temperature exceeds the 90th percentile in the period 1970-1990. The dotted (continuous) lines in Figure 3 show the linear trends for the period 1970-2010 (1991-2010); data were obtained from PAGASA. Years with more than 30 missing values were excluded. A hot day is defined as a day on which the maximum temperature exceeds the 90th percentile in the period 1970-1990. In all three cities, the majority of the respondents claimed to have perceived an increase in the frequency of heat waves ("periods of hot days") (Baguio: 60\%; Tuguegarao: 69.6\%; Dagupan: $85.9 \%$ ). Only for Tuguegarao, these perceptions are confirmed by weather station data for the period of 1990-2010. For Baguio and Dagupan, weather station data actually show downward trends (see Figure 3). However, in 2010 (the year before the survey), all three cities experienced a year with either total numbers of (single) hot days or heat wave days clearly above average (see Figure 3). For Dagupan, weather station data show that there was a below average number of heat wave days in 2009 and 2010, with heat wave defined as a period of five or more consecutive 'hot days'. This indicates 
that the actual number of hot days rather than periods of hot days stand out in local people's memories, i.e., perceptions.

Table 3. Ranks (most mentioned) 1 to 3 for effects of weather events (R5), measures taken (D1, D2), barriers to self-protective behavior (A3); for R5, D2, and A3, multiple answers were allowed, \% indicated.

\begin{tabular}{|c|c|c|c|c|}
\hline & & Baguio $(n=70)$ & Dagupan $(n=71)$ & Tuguegarao $(n=69)$ \\
\hline \multirow{7}{*}{ HEAT } & \multirow{3}{*}{$\begin{array}{l}\text { R5. Reported effects of } \\
\text { weather event (counts) }\end{array}$} & Health (34.3) & Health (47.9) & Health (88.4) \\
\hline & & Mood (32.8) & Mood (21.1) & Mobility/stay \\
\hline & & Livelihood (11.4) & Financial (15.5) & Livelihood/farming (13.0) \\
\hline & $\begin{array}{c}\text { D1-H. Self-protective } \\
\text { measures } \\
\text { Yes/No (Missing) }\end{array}$ & 27.1/71.4 (1.4) & $19.7 / 60.6(19.7)$ & 13.0/75.4 (11.6) \\
\hline & \multirow{3}{*}{$\begin{array}{l}\mathrm{D} 2-\mathrm{H} \text {. Heat } \\
\text { measures taken }\end{array}$} & $\begin{array}{l}\text { Plant backyard } \\
\text { trees }(8.6)\end{array}$ & Stay hydrated (11.3) & Avoid exposure (5.8) \\
\hline & & $\begin{array}{l}\text { Use protective } \\
\text { clothes (5.7) }\end{array}$ & Stay inside (5.6) & $\begin{array}{l}\text { Plant (backyard) } \\
\text { trees }(4.4)\end{array}$ \\
\hline & & Stay hydrated (5.7) & $\begin{array}{l}\text { Plant backyard } \\
\text { trees }(5.6)\end{array}$ & Buy fan (1.5) \\
\hline \multirow{7}{*}{ DROUGHT } & \multirow{3}{*}{$\begin{array}{l}\text { R5. Effects of weather } \\
\text { event (counts) }\end{array}$} & Water shortage (13) & Livelihood/farming (14) & Livelihood/farming (19) \\
\hline & & Personal hygiene (10) & Financial expenses (10) & Water shortage (8) \\
\hline & & Livelihood/farming (9) & Water shortage (8) & Hunger \& thirst (4) \\
\hline & $\begin{array}{c}\text { D1-D. Self-protective } \\
\text { measures } \\
\text { Yes/No (Missing) }\end{array}$ & 20.0/78.6 (1.4) & 11.3/69.0 (19.7) & 20.3/68.1 (11.6) \\
\hline & \multirow{3}{*}{$\begin{array}{l}\text { D2-D. Drought } \\
\text { measures taken }\end{array}$} & Stock water (8.6) & Stock water (9.9) & Conserve water (8.7) \\
\hline & & Conserve water (2.9) & Stock supplies (2.8) & $\begin{array}{l}\text { Alternative } \\
\text { livelihod }(44)\end{array}$ \\
\hline & & Reuse water (2.9) & Reuse water (1.4) & Reduce expenses (2.9) \\
\hline \multirow{6}{*}{ RAIN } & \multirow{3}{*}{$\begin{array}{l}\text { R5. Effects of weather } \\
\text { event (counts) }\end{array}$} & Livelihood/income (32.9) & $\begin{array}{c}\text { Flooded } \\
\text { property }(26.8)\end{array}$ & Livelihood/income (40.6) \\
\hline & & Health (15.7) & Health (23.9) & Health (26.1) \\
\hline & & $\begin{array}{c}\text { Disrupted } \\
\text { routines (14.3) }\end{array}$ & Livelihood/income (22.5) & Flooded property (17.4) \\
\hline & $\begin{array}{c}\text { D1—R. } \\
\text { Yes/No/Missing in \% }\end{array}$ & 68.6/30.0/1.4 & $56.3 / 23.9 / 19.7$ & 66.7/21.7/11.6 \\
\hline & \multirow{2}{*}{$\begin{array}{l}\mathrm{D} 2-\mathrm{R} \text {. Rain } \\
\text { measures taken }\end{array}$} & $\begin{array}{c}\text { Emergency } \\
\text { supplies (37.1) } \\
\text { Fix/secure house (12.9) }\end{array}$ & $\begin{array}{c}\text { Emergency } \\
\text { supplies (18.3) } \\
\text { Fix/secure house (15.5) }\end{array}$ & $\begin{array}{c}\text { Emergency } \\
\text { supplies (18.8) } \\
\text { Plant trees (15.9) }\end{array}$ \\
\hline & & $\begin{array}{l}\text { Clean/avoid } \\
\text { clogging }(8.6)\end{array}$ & Elevated flooring (9.9) & Fix/secure house (10.1) \\
\hline \multirow{5}{*}{ ALL EVENTS } & $\begin{array}{l}\text { D1. Self-protective } \\
\text { behavior } \\
\text { Yes/No/Missing in \% }\end{array}$ & $78.6 / 20.0 / 1.4$ & 60.6/21.1/18.3 & 68.1/20.3/11.6 \\
\hline & \multirow{4}{*}{$\begin{array}{l}\text { A3. Perceived barriers } \\
\text { to self-protective } \\
\text { behavior }\end{array}$} & Unpredictability of & Financial (21.1) & Financial (31.9) \\
\hline & & weather events (34.3) & Unpredictability of & Location (4.4) \\
\hline & & Financial (31.4) & weather events (9.9) & God's will (2.9) \\
\hline & & $\begin{array}{c}\text { Lack of } \\
\text { information (15.7) }\end{array}$ & $\begin{array}{c}\text { Lack of } \\
\text { information (5.6) }\end{array}$ & $\begin{array}{l}\text { Unpredictability of } \\
\text { weather events }(2.9)\end{array}$ \\
\hline
\end{tabular}



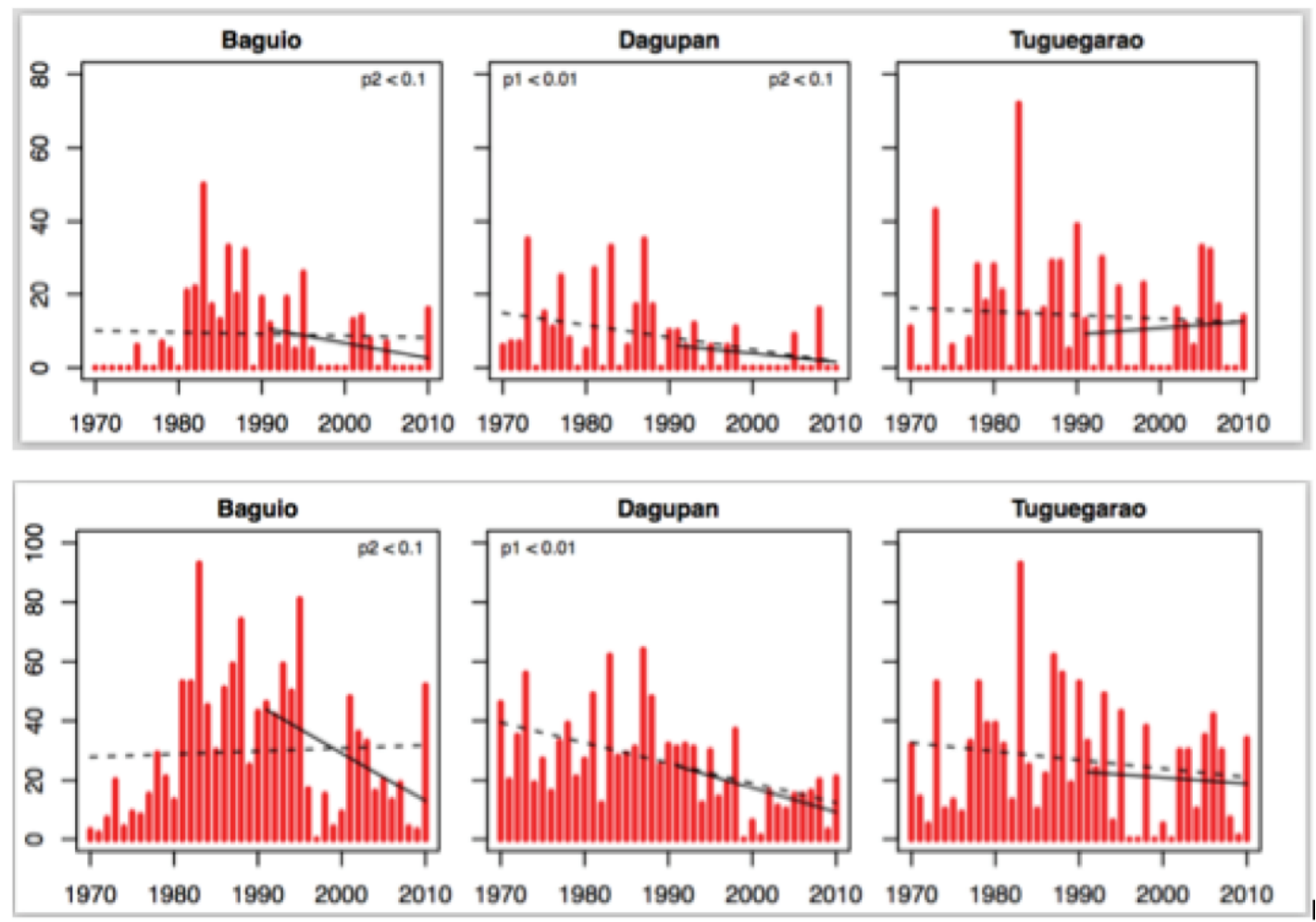

Figure 3. Above: Annual number of heat wave days. Below: Annual frequency of hot days. Linear regressions/trends were calculated for the periods 1970-2010 (dashed lines) and 1991-2010 (solid lines) (Data: PAGASA).

Dry spells: In the past, El Niño Southern Oscillation (ENSO) episodes have caused minor and major droughts in the Philippines [53]. The potential impacts of droughts are mainly relevant to one of the three cities under study, namely Tuguegarao. Tuguegarao is the capital of the Cagayan Province and was identified as being especially affected by droughts [53], posing a crucial risk to crops and livelihoods. The 2009-2010 El Niño event led to heavy drought damages [54]. The perceived change in the frequency of dry spells is by far less extreme than that regarding (periods of) hot days. Still, both in Baguio (45.7\%) and Tuguegarao (43.5\%), almost half of the respondents said they had perceived an increase in those events (Dagupan: $35.2 \%$ ). These perceptions are only partly corroborated by weather records. Based on weather station data, we calculated the Standardized Precipitation Evapotranspiration Index SPEI [55] for three-month periods for the years 1970-2010. The data suggest the year 2010 (shortly before the research was conducted) showed longer dry spells in all three cities than the years before (see Figure 4).

Strong rain: We defined a strong rainfall event as a day on which rainfall exceeds the 90th percentile in the period of observation. The dotted (continuous) lines in Figure 5 show the linear trends for the periods 1970-2010 (1991-2010) (data source: PAGASA). Years with more than 30 missing values have been excluded. A total of $69.5 \%$ of all respondents perceived an increase in the frequency of heavy rain events (between 63.8\% in Tuguegarao and 73.2\% in Dagupan). For the period of 1991-2010, weather station data corroborate this perception regarding all three cities (see Figure 5). For Baguio and Dagupan, this is also the case for the period of 1970-2010, whereas for Tuguegarao, an upward trend for the period of 1970-2010 can only be seen when looking at heavy rain events above the 99th percentile (not pictured). 

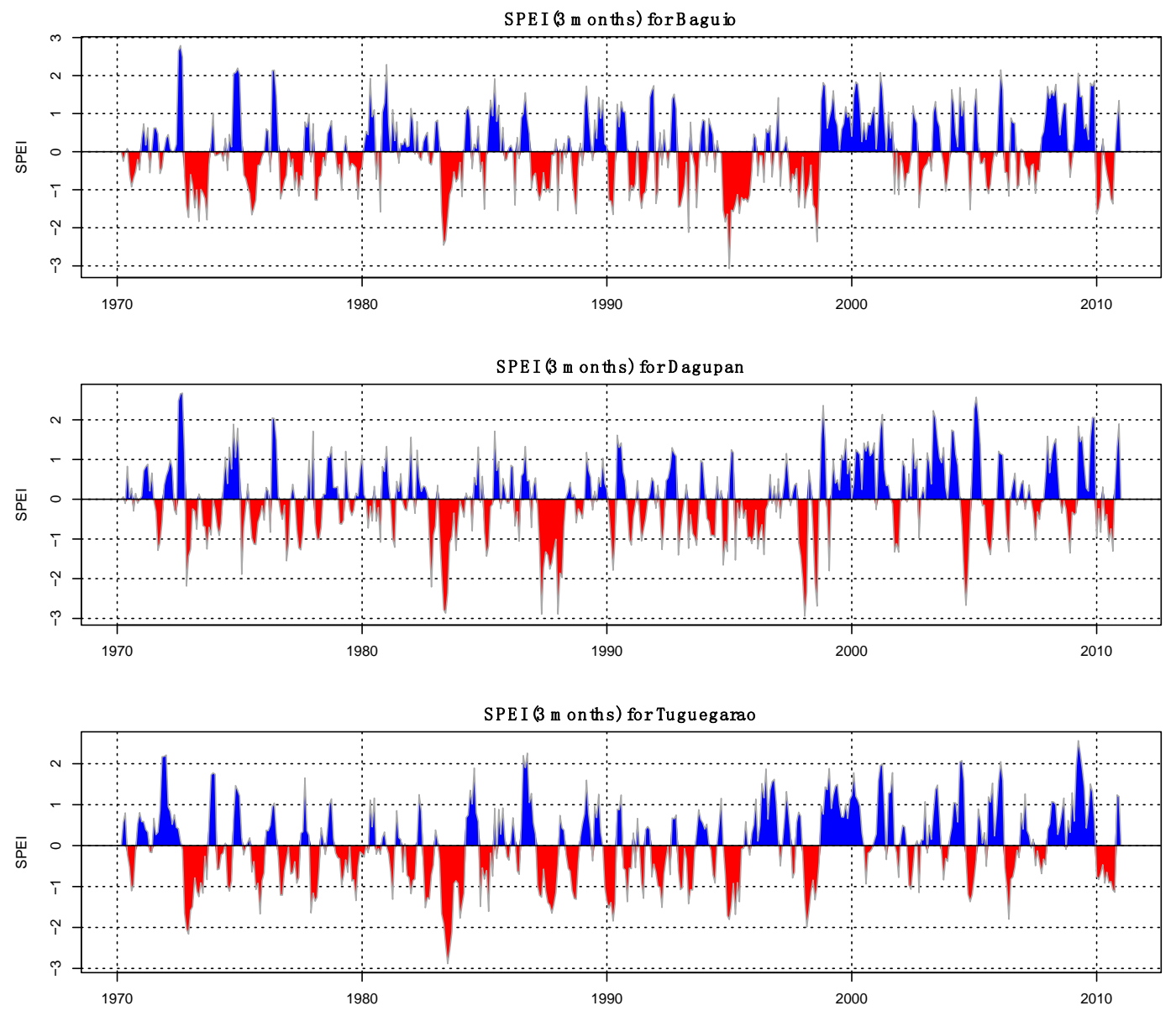

Figure 4. Standardized Precipitation Evapotranspiration Index SPEI for three-month periods for 1970-2010. Values above 0 represent phases with positive climatic water balance; values below 0 represent phases with negative climatic water balance, i.e., drought periods [45] (data source PAGASA).

\subsection{Explanatory Factors for Self-Protective Behavior}

In the following, we depict the results regarding explanatory factors of whether or not people take self-protective measures against the impacts of extreme weather events. In advance, we want to point out that risk perception (factor of R1 and R2 in Table 1) was high for all cities and all weather events. A high risk perception is defined as a value of 15 (5) or higher (see Section 2). For heat and rain, risk perception was high in $82.6-95.7 \%$ of the respondents, for drought between $67.1 \%$ (Dagupan) and $87.7 \%$ (Tuguegarao). On the other hand, only 10\% (Baguio) to $23.2 \%$ (Tuguegarao) of the respondents perceived a high feasibility of self-protective measures (A1 in Table 1) (Dagupan: 21.1\%). Hence, perceptions of personal risks through extreme weather events were rather high, while the perceived feasibility of self-protective measures was rather low among the respondents in the three cities under study.

Table 4 shows correlations and Nagelkerke's $R^{2}$ of all independent variables (see Table 1 ) with the four dependent variables, i.e., the three event-specific measures of self-protective behavior and the overall self-protective behavior regarding all events (see Table S1 in the Supplementary Material for answers in percentage to all items).

\subsubsection{Results Regarding the Overall Sample}

The results described in the following refer to Table 4, i.e., the results of the simple regression analyses. We did not perform hierarchical regression analyses for further analyzing which variables explain self-protective behavior regarding the overall sample, since there were only few variables with 
significant Nagelkerke's $\mathrm{R}^{2}$ values (see Table 4). In addition, in Table 4, it can be seen that there are clear differences between the three cities, so we perceived analyses for the individual cities as more meaningful. The impression of adaptation appraisal having a particularly high impact on self-protective behavior is reinforced when looking at the whole sample rather than at individual cities. Regarding items relevant for risk appraisal, we found no significant relation between any of the variables relevant for risk appraisal (R1-R6) and the likelihood of the respondents to have carried out self-protective measures against any of the three weather extremes (D1). The only significant results found regarded a higher likelihood to carry out self-protective measures against drought (D2—Drought) with increased risk knowledge (R4) and a slightly lower likelihood to carry out measures against heat (D2-Heat) with a livelihood dependent on nature (R6). On the other hand, several variables relevant for adaptation appraisal showed significant correlations with self-protective behavior. The perceived feasibility of self-protective measures (A1) showed the biggest effects on respondents' likelihood to carry out self-protective measures related to strong rain events (D2-R) in all cities except Baguio. Respondents with a high perceived adaptation knowledge (A2) were more likely to carry out self-protective measures (D1). Whether or not people had perceived self-protective measures carried out by others (A4) only played a role in Dagupan for extreme rain events (D2-Rain) and in Tuguegarao for drought events (D2-Drought). People in Baguio holding the belief citizens are responsible for self-protective measures (A5) tended to be more likely to have taken measures (D1). The factor integrating the amount of information from different information sources (A6) and the trust in those sources (A7) corresponded with a higher likelihood to carry out self-protective measures (D1) in both Dagupan and Tuguegarao. Socio-demographic variables seem to play a minor role in our sample, showing only few and low significant effects.
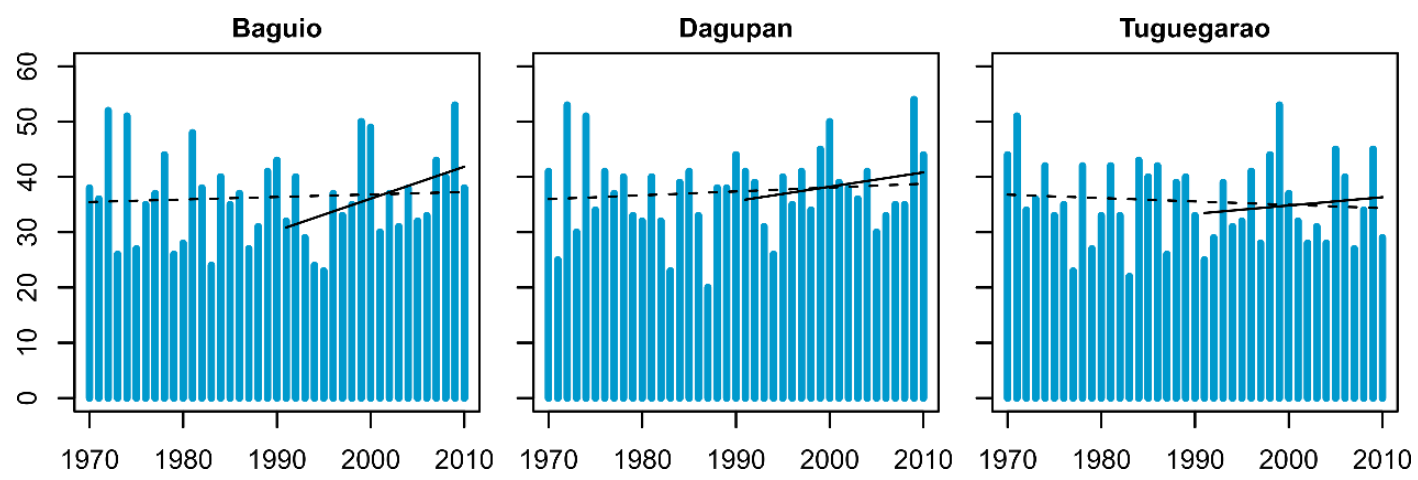

Figure 5. Annual frequency of strong rainfall events $>90$ th percentile (y-axis). Linear regressions/trends were calculated for the periods 1970-2010 (dashed lines) and 1991-2010 (solid lines) (Data source: PAGASA).

\subsubsection{Results Per City}

In the following, we only address relationships between independent and dependent variables that proved to be statistically significant in the simple regression analyses (see Table 4). Those variables with significant Nagelkerke's $R^{2}$ were then fed into hierarchical regression analyses (entry method forward selection likelihood ratio). Results of the latter are also addressed in the following abstracts.

Baguio: Very few of the relationships between the measured independent variables and the dependent measures of self-protective behavior were statistically significant. People who had higher perceived adaptation knowledge (A2) were more likely to have already undertaken self-protective measures regarding strong rain events (D2-Rain). Subjects that agreed with the statement that citizens are responsible to protect themselves (A5) were generally more likely to have undertaken self-protective measures (D1). 
Table 4. Kendall's Tau correlation (first value) and Nagelkerke's $\mathrm{R}^{2}$ (second value) for the factors assumed to be relevant for self-protective behavior and the dependent variables (D1, D2).

\begin{tabular}{|c|c|c|c|c|c|c|}
\hline & $\begin{array}{l}\text { Factors Relevant for } \\
\text { Self-Protective Behavior }\end{array}$ & City & D2-Heat & D2-Drought & D2-Rain & $\begin{array}{c}\text { D1 } \\
\text { All Events }\end{array}$ \\
\hline \multirow{16}{*}{$\begin{array}{l}\text { RISK APPRAISAL } \\
\text { RELATED FACTORS }\end{array}$} & \multirow{4}{*}{ R1+R2. Risk perception } & All cities & $0.12 * / 0.03$ & $-0.05 / 0.00$ & $-0.11 / 0.01$ & $-0.01 / 0.00$ \\
\hline & & Baguio & $0.11 / 0.03$ & $0.05 / 0.02$ & $0.00 / 0.01$ & $0.18 / 0.09$ \\
\hline & & Dagupan & $0.20 / 0.05$ & $0.16 / 0.07$ & $0.09 / 0.01$ & $0.19 / 0.04$ \\
\hline & & Tuguegarao & $0.09 / 0.03$ & $-0.31 * / 0.18 *$ & $-0.45^{* *} / 0.36^{* *}$ & $-0.41^{* *} / 0.32 *$ \\
\hline & \multirow{4}{*}{ R3. Reliance on public adaptation } & All cities & $-0.01 / 0.00$ & $-0.10 / 0.01$ & $0.04 / 0.02$ & $0.06 / 0.01$ \\
\hline & & Baguio & $0.04 / 0.00$ & $0.05 / 0.00$ & $0.02 / 0.00$ & $0.07 / 0.01$ \\
\hline & & Dagupan & $0.03 / 0.00$ & $-0.26 * / 0.12$ & $0.08 / 0.01$ & $0.02 / 0.00$ \\
\hline & & Tuguegarao & $-0.09 / 0.01$ & $-0.14 / 0.03$ & $0.01 / 0.00$ & $0.07 / 0.01$ \\
\hline & \multirow{4}{*}{ R4. Perceived risk knowledge } & All cities & $0.12 / 0.02$ & $0.24^{* *} / 0.10^{* *}$ & $0.11 / 0.02$ & $0.15 * / 0.04 *$ \\
\hline & & Baguio & $0.07 / 0.01$ & $0.04 / 0.00$ & $0.06 / 0.01$ & $0.09 / 0.02$ \\
\hline & & Dagupan & $0.24 * / 0.09$ & $0.23 * / 0.09$ & $0.20 / 0.05$ & $0.24 * / 0.08$ \\
\hline & & Tuguegarao & $0.04 / 0.00$ & $0.45^{* *} / 0.36^{* *}$ & $0.13 / 0.03$ & $0.13 / 0.03$ \\
\hline & \multirow{4}{*}{ R6. Livelihood dependent on nature } & All cities & $-0.15 * / 0.04 *$ & $0.02 / 0.00$ & $-0.02 / 0.00$ & $0.02 / 0.00$ \\
\hline & & Baguio & $-0.09 / 0.01$ & $-0.02 / 0.00$ & $-0.04 / 0.00$ & $0.01 / 0.00$ \\
\hline & & Dagupan & $-0.20 / 0.08$ & $-0.08 / 0.01$ & $-0.18 / 0.04$ & $-0.12 / 0.02$ \\
\hline & & Tuguegarao & $-0.06 / 0.01$ & $0.05 / 0.01$ & $0.10 / 0.02$ & $0.15 / 0.04$ \\
\hline \multirow{8}{*}{$\begin{array}{c}\text { ADAPTATION } \\
\text { APPRAISAL RELATED } \\
\text { FACTORS }\end{array}$} & \multirow{4}{*}{$\begin{array}{l}\text { A1. Perceived feasibility of } \\
\text { self-protective measures }\end{array}$} & All cities & $-0.06 / 0.01$ & $0.03 / 0.00$ & $0.37^{* *} / 0.24^{* *}$ & $0.36^{* *} / 0.23^{* *}$ \\
\hline & & Baguio & $-0.20 * / 0.06$ & $0.13 / 0.03$ & $0.19 / 0.03$ & $0.12 / 0.03$ \\
\hline & & Dagupan & $-0.02 / 0.00$ & $-0.12 / 0.03$ & $0.35^{* *} / 0.22 *$ & $0.35^{* *} / 0.23 *$ \\
\hline & & Tuguegarao & $0.05 / 0.01$ & $0.04 / 0.00$ & $0.56^{* *} / 0.55^{* *}$ & $0.57^{* *} / 0.59^{* *}$ \\
\hline & \multirow{4}{*}{ A2. Perceived adaptation knowledge } & All cities & $0.14^{*} / 0.03$ & $0.23^{* *} / 0.10^{* *}$ & $0.19^{* *} / 0.06^{* *}$ & $0.19^{* * / 0.6 * *}$ \\
\hline & & Baguio & $0.06 / 0.01$ & $0.08 / 0.01$ & $0.25 * / 0.10 *$ & $0.19 / 0.06$ \\
\hline & & Dagupan & $0.34^{* *} / 0.17^{*}$ & $0.34^{* *} / 0.20 *$ & $0.28 * / 0.12 *$ & $0.34^{* *} / 0.18^{*}$ \\
\hline & & Tuguegarao & $0.03 / 0.00$ & $0.35^{* *} / 0.20^{*}$ & $0.09 / 0.01$ & $0.10 / 0.02$ \\
\hline
\end{tabular}


Table 4. Cont.

\begin{tabular}{|c|c|c|c|c|c|c|}
\hline & $\begin{array}{c}\text { Factors Relevant for } \\
\text { Self-Protective Behavior }\end{array}$ & City & D2-Heat & D2-Drought & D2-Rain & $\begin{array}{c}\text { D1 } \\
\text { All Events }\end{array}$ \\
\hline & \multirow{4}{*}{$\begin{array}{l}\text { A4. Perceived self-protection measures } \\
\text { by others }\end{array}$} & All cities & $-0.05 / 0.01$ & $0.15 * / 0.04 *$ & $0.11 / 0.02$ & $0.15 / 0.02$ \\
\hline & & Baguio & $-0.11 / 0.02$ & $0.01 / 0.00$ & $-0.01 / 0.00$ & $-0.06 / 0.01$ \\
\hline & & Dagupan & $0.06 / 0.01$ & $0.03 / 0.00$ & $0.29 * * / 0.13 *$ & $0.29 * / 0.15 *$ \\
\hline & & Tuguegarao & $-0.08 / 0.01$ & $0.46^{* *} / 0.38^{* *}$ & $0.13 / 0.03$ & $0.20 / 0.06$ \\
\hline & \multirow{4}{*}{ A5. Perceived private responsibility } & All cities & $0.01 / 0.00$ & $0.08 / 0.01$ & $0.14 * / 0.04 *$ & $0.16 * / 0.05 *$ \\
\hline & & Baguio & $-0.01 / 0.00$ & $0.20 * / 0.09$ & $0.14 / 0.04$ & $0.23 * / 0.09 *$ \\
\hline & & Dagupan & $0.20 / 0.08$ & $0.07 / 0.00$ & $0.24 * / 0.07$ & $0.18 / 0.02$ \\
\hline & & Tuguegarao & $-0.22 / 0.05$ & $0.01 / 0.00$ & $0.05 / 0.02$ & $0.09 / 0.03$ \\
\hline & \multirow{4}{*}{$\begin{array}{l}\text { A6+A7. Information from }(A 6)+\text { trust in } \\
\text { all information sources (A7) }\end{array}$} & All cities & $0.07 / 0.02$ & $0.17^{* *} / 0.08^{*}$ & $0.19^{* *} / 0.08^{* *}$ & $0.19^{* *} / 0.10^{* *}$ \\
\hline & & Baguio & $-0.10 / 0.01$ & $0.06 / 0.01$ & $0.03 / 0.01$ & $-0.03 / 0.01$ \\
\hline & & Dagupan & $0.32 * * / 0.20 *$ & $0.28 * / 0.19 *$ & $0.30 / 0.19^{*}$ & $0.33^{* *} / 0.22 *$ \\
\hline & & Tuguegarao & $0.04 / 0.03$ & $0.29 * / 0.23$ & $0.33^{* *} / 0.16$ & $0.33^{* *} / 0.16$ \\
\hline \multirow{16}{*}{$\begin{array}{l}\text { SOCIO-DEMOGRAPHIC } \\
\text { FACTORS }\end{array}$} & \multirow{4}{*}{$\begin{array}{c}\text { S1. Age } \\
\text { (Positive correlation indicates younger } \\
\text { people are more likely to have carried } \\
\text { out self-protective measures.) }\end{array}$} & All cities & $-0.07 / 0.01$ & $-0.07 / 0.01$ & $0.02 / 0.00$ & $0.01 / 0.00$ \\
\hline & & Baguio & $-0.04 / 0.00$ & $-0.10 / 0.01$ & $0.02 / 0.00$ & $0.00 / 0.00$ \\
\hline & & Dagupan & $-0.20 * / 0.06$ & $0.02 / 0.00$ & $0.09 / 0.02$ & $0.11 / 0.03$ \\
\hline & & Tuguegarao & $0.05 / 0.01$ & $-0.20 * / 0.08$ & $-0.16 / 0.03$ & $-0.12 / 0.01$ \\
\hline & \multirow{4}{*}{$\begin{array}{c}\text { S2. Gender } \\
\text { (Positive correlation indicates men are } \\
\text { more likely to have carried out } \\
\text { self-protective measures.) }\end{array}$} & All cities & $0.05 / 0.00$ & $-0.05 / 0.01$ & $-0.15 * / 0.03 *$ & $-0.07 / 0.01$ \\
\hline & & Baguio & $0.14 / 0.03$ & $0.04 / 0.00$ & $-0.21^{*} / 0.06$ & $-0.04 / 0.00$ \\
\hline & & Dagupan & $-0.14 / 0.03$ & $-0.23 * / 0.15$ & $-0.34^{* *} / 0.15^{*}$ & $-0.31^{* *} / 0.13^{*}$ \\
\hline & & Tuguegarao & $0.09 / 0.01$ & $-0.07 / 0.01$ & $0.09 / 0.01$ & $0.07 / 0.01$ \\
\hline & \multirow{4}{*}{ S3. Educational level } & All cities & $0.16 * / 0.04 *$ & $0.10 / 0.03$ & $0.13 * / 0.03$ & $0.14 * / 0.04 *$ \\
\hline & & Baguio & $0.20 * / 0.06$ & $0.09 / 0.02$ & $0.10 / 0.01$ & $0.06 / 0.00$ \\
\hline & & Dagupan & $0.16 / 0.08$ & $0.17 / 0.10$ & $0.32 * / 0.18^{*}$ & $0.37^{* *} / 0.24^{* *}$ \\
\hline & & Tuguegarao & $-0.03 / 0.01$ & $0.22 * / 0.07$ & $0.17 / 0.04$ & $0.14 / 0.03$ \\
\hline & \multirow{4}{*}{$\begin{array}{l}\text { S4. Household status } \\
\text { (Source for cooking) }\end{array}$} & All cities & $0.17 * / 0.05^{*}$ & $0.13 * / 0.03$ & $0.13 * / 0.03$ & $0.16 * / 0.04 *$ \\
\hline & & Baguio & $0.14 / 0.03$ & $0.09 / 0.01$ & $0.02 / 0.00$ & $0.02 / 0.00$ \\
\hline & & Dagupan & $0.22 / 0.11$ & $0.15 / 0.07$ & $0.24 * / 0.07$ & $0.28 * / 0.10 *$ \\
\hline & & Tuguegarao & $0.06 / 0.01$ & $0.24 * / 0.09$ & $0.26^{* *} / 0.10$ & $0.23 * / 0.08$ \\
\hline
\end{tabular}

* significant at $p<0.05 ;{ }^{* *}$ significant at $p<0.01$; Nagelkerke's $\mathrm{R}^{2}$ was calculated for each independent variable individually. For Nagelkerke's $\mathrm{R}^{2}$, the asterisks indicate a significant influence of the respective independent variable on the respective dependent variable. 
Dagupan: We found a medium correlation for the perceived feasibility of self-protective measures (A1) and the likelihood to take on self-protective measures regarding strong rain (D2-Rain). In addition, perceived adaptation knowledge (A2) explained variation in whether people had taken self-protective measures for any of the three addressed extreme weather events (D2-Heat/Drought/Rain, D1). Regarding rain-related measures (D2-Rain), whether people had perceived protective measures undertaken by others (A4) also had an influence on their own self-protective behavior. The more information people receive and trust the information sources (A6+A7), the more likely they were to have taken self-protective measures regarding all three weather events (D2-Heat/Drought/Rain, D1). For socio-demographic variables, we only found significant relationships of the educational level (S3) and of gender (S2; women being more active) with self-protective measures against rain (D2-Rain) and all events (D1).

The second step of analysis (hierarchical regression analysis) confirmed that variables relevant for adaptation appraisal show a stronger relation with self-protective behavior than risk appraisal and socio-demographic variables. The results in detail are:

For D1-Self-protective behavior regarding all events, the following variables were fed into a hierarchical regression analysis based on the results of the simple regressions: In block one, A1-Perceived feasibility of self-protective measures, A2-Perceived adaptation knowledge, A4-Perceived self-protection measures by others, and A6+A7-Information from and trust in all information sources; in block two, S2-Gender, S3-Educational level, and S4-Household status. The model was significant (Chi-square $(1)=8.09, p=0.004$ ), with the only variable included in the final model being A4-Perceived measures by others $(B=2.17, \operatorname{Exp}(B)=8.77, p=0.015)$. Nagelkerkes's $R^{2}$ was 0.33 .

For D2-Heat, the following variables were fed into a hierarchical regression analysis (one block only): A2-Perceived adaptation knowledge and A6+A7-Information from and trust in all information sources. The model was significant (Chi-square $(1)=5.98, p=0.014)$, with the only variable included in the final model being A2-Perceived adaptation knowledge $(B=1.73, \operatorname{Exp}(B)=5.61, p=0.022)$. Nagelkerke's R2 was 0.19 .

For D2-Drought, also A2-Perceived adaptation knowledge and A6+A7-Information from and trust in information sources were fed into a hierarchical regression analysis. The model was significant (Chi-square $(1)=5.46, p=0.020$ ), with the only variable included in the final model being, again, A2-Perceived adaptation knowledge $(B=1.87, \operatorname{Exp}(B)=6.47, p=0.028)$. Nagelkerkes's $R^{2}$ was 0.20 .

For D2-Rain, the following variables were fed into a hierarchical regression analysis: in block one, A1-Perceived feasibility of self-protective measures, A2-Perceived adaptation knowledge, A4-Perceived self-protection measures by others, and A6+A7-Information from and trust in information sources; in block two, S2-Gender. The model was significant with (Chi-square(3) $=16.98$, $p=0.001)$, with the A1-Perceived feasibility of self-protective measures $(B=3.12, \operatorname{Exp}(B)=22.57$, $p=0.018), A 6+A 7$ Information from and trust in information sources $(B=0.06, \operatorname{Exp}(B)=1.06, p=0.483)$, and S2-Gender $(B=-2.69, \operatorname{Exp}(B)=0.068, p=0.030)$ included in the final model. Nagelkerke's $R^{2}$ was 0.53 .

Tuguegarao: As opposed to the expected positive relation between risk perception and self-protective behavior, people in Tuguegarao with elevated risk perception $(R 1+R 2)$ were actually less likely to carry out drought- and heat-related self-protective measures (D2-Drought and D2-Heat). We found medium to high correlations between the likelihood to have carried out measures against drought (D2-Drought) and (a) perceived risk knowledge (R4), (b) perceived adaptation knowledge (A2), and (c) perception of self-protective measures carried out by others (A4). As for respondents' likelihood to have carried out self-protective measures against the impacts of strong rain events $(\mathrm{D} 2-\mathrm{R})$, there was only a significant positive correlation with the perceived feasibility of precautionary measures (A1). The second step of the analysis, again, however, with some exceptions, confirmed that variables relevant for adaptation appraisal show stronger relations with self-protective behavior than risk appraisal and socio-demographic variables. The results in detail are: 
For D1-Self-protective behavior regarding all events, the following variables were fed into a hierarchical regression analysis based on the results of the simple regressions: in block one, R1+R2-Risk perception and in block 2, A1-Perceived feasibility of self-protective measures. The model was significant (Chi-square $(2)=20.81, p=0.000$ ), with both variables included in the final model, namely $\mathrm{R} 1+\mathrm{R} 2$-Risk perception $(\mathrm{B}=-0.41, \operatorname{Exp}(\mathrm{B})=0.67, p=0.344)$ and $\mathrm{A} 1$-Perceived feasibility of self-protective measures $(B=3.19, \operatorname{Exp}(B)=24.25, p=0.015)$. Nagelkerkes's $R^{2}$ was 0.60 .

For D2-Drought, the following variables were fed into the hierarchical regression: in block one, R1+R2-Risk perception and R4-Perceived risk knowledge; in block two, A2-Perceived adaptation knowledge and A4-Perceived measures by others. The model was significant (Chi-square(3) = 20.61, $p=0.000)$, with three variables included in the final model, namely $\mathrm{R} 1+\mathrm{R} 2-$ Risk perception $(\mathrm{B}=-0.59$, $\operatorname{Exp}(B)=0.56, p=0.044), R 4-P e r c e i v e d$ risk knowledge $(B=-0.39, \operatorname{Exp}(B)=0.68, p=0.71)$, and $A 4-P e r c e i v e d$ measures by others $(B=3.53, \operatorname{Exp}(B)=33.98, p=0.020)$. Nagelkerkes's $R^{2}$ was 0.60 .

For D2-Rain, the following variables were fed into a hierarchical regression: in block one, R1+R2-Risk perception; in block two, A1-Perceived feasibility of self-protective measures and A6+A7-Information from and trust in information sources. The final model was significant (Chi-square $(1)=6.92, p=0.009)$, with A1-Perceived feasibility of self-protective measures $(B=2.69$, $\operatorname{Exp}(B)=14.78, p=0.031$ ) being the only variable included in the final model. Nagelkerkes's $R^{2}$ was 0.37. We did not perform a multiple regression analysis for D2-Heat due to a lack of significant results from the simple regression analysis (see Table 4).

To sum up, for our sample, mainly variables that are relevant for adaptation appraisal, namely perceived feasibility (A1), perceived adaptation knowledge (A2), and perceived self-protective measures by others (A4), accounted for variances concerning whether people carried out self-protective measures, with an exception of Tuguegarao, where the risk perception factor had a significant (negative) influence on self-protective measures against drought. Self-protective behavior could be well explained by the independent variables, particularly for the cities of Dagupan and Tuguegarao, and particularly regarding strong rain events and droughts. Nagelkerke's $\mathrm{R}^{2}$ ranged between 0.19 and 0.60, which equates strong effect sizes (between $d=0.48$ and $d=1.22$ ) according to Cohen [56]. In Baguio, explained variances of self-protective behavior against were much lower and we did not perform any hierarchical regression analyses for the data concerning this city.

\section{Discussion and Conclusions}

We were able to show differences concerning the perception of weather extremes as well as regarding the included independent variables and their predictive power for self-protective behavior between the samples from the three different cities. All over, variables relevant for adaptation appraisal seem to be of high relevance when explaining self-protective behavior. Our results also show that the MPPACC needs to be refined and further variables included. We will reflect on these issues in the following. Firstly, we address limitations of this study due to issues concerning sample size and selection, a potential cultural bias, date of research as well as due to some methodological aspects, some of them owing to a lack of financial resources and time. The non-random sample of only 210 respondents clearly limits the generalizability of our results. The results should be interpreted tentatively, and further research is necessary to validate our results. Further limitations regarding the generalizability of the results can be put down to the lack of (cultural) validation of the questionnaire. Additional to the iterative process of question development with local research partners, an actual field test of the questionnaire would have been desirable. The MPPACC was developed based on data from predominantly 'WEIRD' (Western, educated, industrialized, rich, and democratic) $[57,58]$ populations with mainly individualistic cultures. Yet, the dependent variables refer to individual, self-initiated household-level measures, representing a rather individualistic perspective. In addition, some variables are measured by just one item (e.g., A1-perceived feasibility of self-protective measures), not allowing for testing of internal reliability. However, interviews were conducted as face-to-face interviews on the street, making a short and easy-to-understand questionnaire mandatory. Furthermore, analyzing 
the direct effect of variables such as "reliance on public adaptation" on self-protective behavior is a simplification of the MPPACC, which assumes an effect mediated by risk perception; further research is necessary to analyze how the variables influence each other, including analyses of moderator and mediator variables as well as interaction effects.

Additionally, changes that have taken place since the time of data collection (2011) should be considered when interpreting our results: The percentage of Internet usage has dramatically increased from $29 \%$ in 2011 to $60.1 \%$ in 2017 [59]. Depending on the source, information from the Internet can be (perceived as) information from peers and can, therefore, become an important driver of self-protective action against the impacts of natural disasters [60]. In addition, climate change communication has made good progress [61] and several governmental and non-governmental strategies have been implemented since then [8]. In 2010, the Philippines instituted relevant legislation by passing the Philippine Disaster Risk Reduction and Management Act and adopted the National Strategy on Climate Change Adaptation, offering guidance for adaptation measures [62]. Visible protective measures might influence risk perception, reliance on public protective measures or, when effective, perceived severity of weather extremes. However, we assume that while the influence of those changes on the absolute values of those variables may be high, the influence on shaping the relations between those variables and self-protective behavior that were under study is comparatively low.

At the same time, a shift towards the norm of self-protective behavior has been emerging [63], with a potentially substantial influence on the occurrence of self-protective behavior. It has also been shown that social networks, cohesion, and norms influence an individual's likelihood to engage in behavioral adaptation [57]. In our study, we only marginally measured the perception of social norms by including "perceived self-protection measures by others". When refining (the operationalization of) the MPPACC, variables regarding the perception of social norms and people's social context should be included (also see [22]). Furthermore, we consider the lack of emotions as an independent variable as a weakness of the MPPACC and our study in general since i.e., Bamberg et al. found flood-related emotions to act as direct determinants of flood-preventive intentions or behaviors [21]. It can be assumed that the inclusion of variables measuring hazard-related emotions in our study and the questionnaire, respectively, would have altered our results.

Keeping the described limitations in mind, we describe some possible conclusions based on our results in the following and point out where further research is needed. Again, the main aim of this study was to better understand the level of, and explanatory factors for, self-protective behavior of private households against natural hazards in the Philippines. Almost $70 \%$ of our sample reported self-protective measures. Many of these were reactive (e.g., staying inside the house during heavy rain events) rather than truly precautionary (e.g., elevating the flooring of a house). Hence, there was a lack of precautionary measures in the three cities under study. Furthermore, self-protective measures were mainly reported for strong rain events, indicating a lack of self-protective measures against heat and drought. Other researchers also observed such a focus on rather reactive measures, concerning both measures taken by private households [64] and at the municipal level [65]. However, reactive responses to threats are often inefficient [66] and thus, fostering truly proactive measures seems indispensable.

To explain self-protective behavior, we have built on the Model of Private Proactive Adaptation to Climate Change (MPPACC; see Figure 1) [14] and extended the model by several variables. The MPPACC was originally developed to explain proactive rather than reactive behavior, which was the predominating behavior in our sample. Still, the extended MPPACC explained the self-protective measures taken by the respondents relatively well, particularly in the cities of Dagupan and Tuguegarao, regarding measures against damage from strong rain events and droughts. In the city of Baguio, the extended MPPACC had much lower explanatory power regarding self-protective behavior. Reasons for this are open to speculation. Baguio has a rather mild subtropical highland climate with much lower annual mean temperatures and fewer and shorter dry spells than the other two cities. Regarding heat and drought, this can imply that people from Baguio might simply have put less thought into their personal risks and their potentially necessary options for self-protection. 
The adaptation appraisal variables were particularly influential for self-protective behavior, namely perceived feasibility of self-protective measures, adaptation knowledge, and perceived self-protective measures by others. This strong influence is consistent with many other studies explaining self-protective behavior. In their meta-analyses, Valkengoed and Steg [22], including 106 studies on self-protective behavior concerning weather extremes, identified self-efficacy and outcome efficacy beliefs-both were combined in our variable "perceived feasibility of self-protective measures"-being amongst the most important factors of self-protective behavior (also see [67]). Risk appraisal variables contributed only to a small extent to explaining reported self-protective behavior, but Valkengoed and Steg [22] also found lower explanatory power for risk perception than for factors related to adaptation appraisal such as self-efficacy and outcome efficacy beliefs. One reason for the small influence of risk appraisal variables on self-protective behavior might have been potential feedback from self-protective behavior on risk perception, leading to reduced risk perception [63]. People might have had reduced risk perceptions due to their self-protective behavior, so that an originally positive relation between risk perception and self-protective behavior dwindled or even turned negative as in the case of Tuguegarao. Future longitudinal studies might address the question if, when, and to what extent these potential feedback effects actually occur.

An interesting result is the role of knowledge in self-protective behavior in our study. Perceived risk knowledge correlated up to 0.45 with self-protective behavior against droughts in Tuguegarao. Perceived adaptation knowledge correlated with self-protective behavior in all cities, the highest correlation occurring in Tuguegarao $(r=0.35)$. In their meta-analyses, Valkengoed and Steg have found a much lower mean correlation of only 0.14 between knowledge and adaptation behavior or intention [27]. However, a study from Vietnam also found a high influence of climate change knowledge on the intention to take action to reduce climate change risks [68]. Further research on the role of knowledge in self-protective behavior is needed.

A further aim of this study was to understand the accuracy of the risk experience appraisal, which is considered an influential factor for risk appraisal in the MPPACC [11]. The comparison of the perception of weather trends and the actual weather trends as calculated on the basis of weather station data offered inconclusive results: For days with heavy rain, actual trends corroborate the perception of the respondents. The increase in the frequency of hot days as perceived by a big majority of the sample seems to mainly be connected with very recent memory. As for dry spells, nearly half of the respondents perceived an increase in frequency that is not supported by our analyses of weather station data, but, again, might be influenced by drought events in the very recent past before the time of research. One possible explanation for the strong role of recent memories in shaping people's perceptions is the availability heuristic. This refers to a mental shortcut people make use of to estimate the frequency of a certain event [69]. Furthermore, differences in perception between the respondents from different cities did not correspond with differences in actual weather trends in those cities. Reasons for this might be found again in the strong influence of very recent memory and the availability heuristic, but also in a general perception of climate change as a major risk to the Philippine nation-with $66 \%$ of the Filipinos perceiving climate change as a threat to the nation [70]. This might also explain the lack of discrimination in people's perception regarding their own city as opposed to their country.

We conclude that as much as self-protective behavior against weather extremes needs to be tailored to local needs and projections of future weather trends [42], the geographical context, i.e., what city people live in and what weather trends those cities were exposed to in the past, plays a minor role compared to questions of social context, such as whether people are informed and know about the possibilities of protecting themselves, whether they actually believe that they can carry out effective protective measures and, within limits, the perception of actions taken by neighbors or friends. Consequently, the question of whether people take self-protective measures should probably be looked at from a more socially contextualized perspective than the PMT or the MPPACC allow for. This would imply considering the social environment more strongly and including the role of 
perception of social norms and collective efficacy beliefs [71]. At the same time, when trying to motivate people to take self-protective measures against a certain type of weather extreme, we strongly support the idea of making use of the "window of opportunity" right after the occurrence of an extreme weather event [72,73], making use of the availability heuristic [69] for motivating people to take self-protective measures against the next event.

Many of the measures taken as reported by the respondents classify as measures of a reactive rather than a proactive nature. The lack of truly precautionary measures reveals the need to further educate people on protecting themselves proactively from the impacts of weather extremes. At the same time, people need to be provided the resources to do so, since proactive measures like elevating the flooring of a house are often costly [74]. The lack of risk perception as a positive influence on self-protective behavior in our study, and to some extent, in other studies [67], might be partly explained by feedback effects as described above and the generally very high risk perception among the Filipinos [70]. Factors relevant to adaptation appraisal, such as knowledge about self-protective measures, beliefs in their feasibility and effectiveness, perceived responsibilities, and perceived protective measures of others, were much more important. A very practical conclusion would be that, when aiming at fostering private precautionary measures, municipal administrations and locally active NGOs should try to establish, empower, and communicate role models of self-protective behavior in vulnerable residential areas. Such role models show their neighbors that precautionary action is feasible and can provide information about, as well as practical advice on, adequate precautionary measures, while establishing social norms for self-protective behavior [75].

Supplementary Materials: The following are available online at http://www.mdpi.com/2071-1050/12/15/6010/s1, Table S1. Questionnaire 'Citizen Perception Survey - Weather changes in your city'; items and responses in \% (with coding in brackets) per city and for the overall sample; Table S2. KMO- and Bartlett-Test for variables R1 and R2.; Table S3 Component matrix with factor loadings for variables R1 (perceived future probability of rain, heat, drought) and R2 (perceived severity of effects of rain, heat, drought); Figure S1 Scree plot with Eigenvalues for factor analysis factor "risk perception"; Factor "Information from and trust in all information sources": Table S4 KMO- and Bartlett-Test for variables A6 and A7; Table S5 Component matrix with factor loadings for variables A6 (Information on changes and measures from different sources) and A7 (trust in different information sources); Figure S2 Screeplot with Eigenvalues for factor analysis factor "Information from and trust in all information sources".

Author Contributions: Conceptualization and methodology were developed by J.L.W. and T.G.; analysis of weather station data and map design was carried out by M.S.; general guidance on drafting and editing was provided by H.A.M.; analysis of survey data and drafting and editing of the paper by J.L.W. All authors have read and agreed to the published version of the manuscript.

Funding: The project "Asian Cities Adapt", in which the data collection and part of the data analysis were conducted, was funded within the International Climate Initiative by the Federal Ministry for the Environment, Nature Conservation and Nuclear Safety (BMU); the project lead was with ICLEI European Secretariat GmbH. Most of the research work was carried out without any funding.

Acknowledgments: Part of the research was done within the project "Asian Cities Adapt" at the Potsdam Institute of Climate Impact Research (PIK) when J.W., T.G. and M.S. were affiliated with the PIK. We acknowledge the valuable support of the ICLEI European Secretariat and ICLEI South-East Asia Secretariat for their valuable support, in particular in coordinating research activities in partner cities. We acknowledge support by the German Research Foundation (DFG) and the Open Access Publication Fund of Humboldt-University Berlin.

Conflicts of Interest: The authors declare no conflict of interest.

Annotation: Ethical approval was not necessary in the context of the study due to research regulations in Germany/at the Potsdam Institute for Climate Impact Research. Consent was obtained through the respondents participating in the interview. Information on anonymity was given before the interviews were conducted. 


\section{References}

1. Kreft, S.; Eckstein, D.; Dorsch, L.; Fischer, L. Global Climate Risk Index-Who Suffers Most from Extreme Weather Events? Weather-Related Loss Events in 2014 and 1995-2014; Briefing Paper; Germanwatch: Bonn, Germany, 2015.

2. Intergovernmental Panel on Climate Change (IPCC). Climate Change 2013: The Physical Science Basis. Contribution of Working Group I to the Fifth Assessment Report of the Intergovernmental Panel on Climate Change; Cambridge University Press: Cambridge, UK, 2013.

3. Intergovernmental Panel on Climate Change (IPCC). Climate Change 2014: Impacts, Adaptation, and Vulnerability. Part B: Regional Aspects. Contribution of Working Group II to the Fifth Assessment Report of the Intergovernmental Panel on Climate Change; Cambridge University Press: Cambridge, UK, 2014.

4. Government of the Philippines. Second National Communication to the United Nations Framework Convention on Climate Change; 2014. Available online: http://unfccc.int/resource/docs/natc/phlnc2.pdf (accessed on 17 October 2019).

5. Jaranilla-Sanchez, P.A.; Wang, L.; Koike, T. Modeling the hydrologic responses of the Pampanga River basin, Philippines: A quantitative approach for identifying droughts. Water Resour. Res. 2011, 47. [CrossRef]

6. World Bank and United Nations. Natural Hazards, Unnatural Disasters: The Economics of Effective Prevention; The World Bank: Washington, DC, USA, 2010.

7. Center for Excellence in Disaster Management and Humanitarian Assistance. Philippines-Disaster Management Reference Handbook. 2018. Available online: https://reliefweb.int/sites/reliefweb.int/files/resources/ Philippines_2018-0318.pdf (accessed on 17 September 2019).

8. Swiss NGO DRR Platform. Disaster Risk Reduction and Management in the Philippines. 2014. Available online: https: //www.shareweb.ch/site/DRR/Documents/About\%20Us/Risk_Assessment_Philippines_2014.pdf (accessed on 15 August 2018).

9. Ajzen, I. The theory of planned behavior. Organ. Behav. Hum. Decis. Process. 1991, 50, 179-211. [CrossRef]

10. Najafi, M.; Ardalan, A.; Akbarisari, A.; Noorbala, A.A.; Elmi, H. The theory of planned behavior and disaster preparedness. PLoS Curr. 2017, 9, 5143824. [CrossRef]

11. Daellenbach, K.; Parkinson, J.; Krisjanous, J. Just how prepared are you? An application of marketing segmentation and theory of planned behavior for disaster preparation. J. Nonprofit Public Sect. Mark. 2018, 30, 413-443. [CrossRef]

12. Mulilis, J.-P.; Duval, T.S. Negative Threat Appeals and Earthquake Preparedness: A Person-Relative-to-Event (PrE) Model of Coping with Threat. J. Appl. Soc. Psychol. 1995, 25, 1319-1339. [CrossRef]

13. Lindell, M.K.; Perry, R.W. The Protective Action Decision Model: Theoretical Modifications and Additional Evidence. Risk Anal. 2012, 32, 616-632. [CrossRef]

14. Grothmann, T.; Patt, A. Adaptive capacity and human cognition: The process of individual adaptation to climate change. Glob. Environ. Chang. 2005, 15, 199-213. [CrossRef]

15. Rogers, R.W. Cognitive and Physiological Processes in Fear Appeals and Attitude Change: A Revised Theory of Protection Motivation; Cacioppo, B.L., Petty, L.L., Eds.; Guilford Press: New York, NY, USA, 1983; pp. $153-177$.

16. Rogers, R.W.; Prentice-Dunn, S. Protection motivation theory. In Handbook of Health Behaviour Research. I: Personal and Social Determinants; Gochman, D.S., Ed.; Plenum Press: New York, NY, USA, 1997; pp. $113-132$.

17. Zheng, Y.; Dallimer, M. What motivates rural households to adapt to climate change? Clim. Dev. 2016, 8, 110-121. [CrossRef]

18. Kuruppu, N.; Liverman, D. Mental preparation for climate adaptation: The role of cognition and culture in enhancing adaptive capacity of water management in Kiribati. Glob. Environ. Chang. 2011, 21, 657-669. [CrossRef]

19. Siedschlag, D. Hochwasser E Eigenvorsorge-Untersuchung von Einflussfaktoren Persönlicher Schutzmaßnahmen. 2010. (In German). Available online: https://www.econstor.eu/bitstream/10419/57862/1/647139170.pdf (accessed on 3 March 2020).

20. Grothmann, R.; Reusswig, F. People at risk of flooding: Why some residents take precautionary action while others do not. Nat. Hazards 2006, 38, 101-120. [CrossRef]

21. Bamberg, S.; Masson, T.; Brewitt, K.; Nemetschek, N. Threat, coping and flood prevention-A meta-analysis. J. Environ. Psychol. 2017, 54, 116-126. [CrossRef]

22. van Valkengoed, A.M.; Steg, L. Meta-analyses of factors motivating climate change adaptation behaviour. Nat. Clim. Chang. 2019, 9, 158-163. [CrossRef] 
23. Grothmann, T. Wetterextreme und Private Schadensprävention-Enwicklung, Überprüfung und Praktische Anwendbarkeit der Theorie Privater Proaktiver Wetterextrem-Vorsorge; Otto-von-Guericke-Universität: Magdeburg, Germany, 2005.

24. Adeola, F. Katrina cataclysm: Does Duration of Residency and Prior Experience Affect Impacts, Evacuation, and Adaptation Behavior among Survivors? Environ. Behav. 2009, 41, 459-489. [CrossRef]

25. Peacock, W.G. Hurricane mitigation status and factors influencing mitigation status among Florida's single-family homeowners. Nat. Hazards Rev. 2003, 4, 149-158. [CrossRef]

26. Lo, A.Y. The role of social norms in climate adaptation: Mediating risk perception and flood insurance purchase. Glob. Environ. Chang. 2013, 23, 1249-1257. [CrossRef]

27. Peacock, W.G.; Brody, S.D.; Highfield, W. Hurricane risk perceptions among Florida's single family homeowners. Landsc. Urban Plan. 2005, 73, 120-135. [CrossRef]

28. Kuhlicke, C.; Scolobig, A.; Tapsell, S.; Steinführer, A.; De Marchi, B. Contextualizing social vulnerability: Findings from case studies across Europe. Nat. Hazards 2011, 58, 789-810. [CrossRef]

29. Scolobig, A.; De Marchi, B.; Borga, M. The missing link between flood risk awareness and preparedness: Findings from case studies in an Alpine Region. Nat. Hazards 2012, 63, 499-520. [CrossRef]

30. Arbuckle, J.G., Jr.; Morton, L.W.; Hobbs, J. Understanding Farmer Perspectives on Climate Change Adaptation and Mitigation: The Roles of Trust in Sources of Climate Information, Climate Change Beliefs, and Perceived Risk. Environ. Behav. 2013, 47, 205-234. [CrossRef]

31. Frank, E.; Eakin, H.; López-Carr, D. Social identity, perception and motivation in adaptation to climate risk in the coffee sector of Chiapas, Mexico. Glob. Environ. Chang. 2011, 21, 66-76. [CrossRef]

32. Waibel, H.; Pahlisch, T.H.; Völker, M. Farmers' perceptions of and adaptations to climate change in Southeast Asia: The case study from Thailand and Vietnam. In Climate Smart Agriculture; Springer: Cham, Switzerland, 2018; pp. 137-160.

33. Werg, J.; Grothmann, T.; Schmidt, P. Assessing social capacity and vulnerability of private households to natural hazards-integrating psychological and governance factors. Nat. Hazards Earth Syst. Sci. 2013, 13, 1613-1628. [CrossRef]

34. Botzen, W.J.W.; Aerts, J.C.J.H.; Bergh, J.C.J.M. Willingness of homeowners to mitigate climate risk through insurance. Ecol. Econ. 2009, 68, 2265-2277. [CrossRef]

35. Toole, S.; Klocker, N.; Head, L. Re-thinking climate change adaptation and capacities at the household scale. Clim. Chang. 2016, 135, 203-209. [CrossRef]

36. Dietz, T.; Dan, A.; Shwom, R. Support for climate change policy: Social psychological and social structural influences. Rural Sociol. 2007, 72, 185-214. [CrossRef]

37. Cologna, V.; Siegrist, M. The role of trust for climate change mitigation and adaptation behaviour: A meta-analysis. J. Environ. Psychol. 2020, 101428. [CrossRef]

38. Moyo, M.; Mvumi, B.M.; Kunzekweguta, M.; Mazvimavi, K.; Craufurd, P.; Dorward, P. Farmer perceptions on climate change and variability in semi-arid Zimbabwe in relation to climatology evidence. Afr. Crop Sci. J. 2012, 20, 317-335.

39. Bradford, R.A.; O'Sullivan, J.J.; Craats, I.M.; Krykow, J.; Rotko, P.; Aaltonen, J.; Bonaiuto, M.; De Dominicis, S.; Waylen, K.; Schelfaut, K. Risk perception-Issues for flood management in Europe. Nat. Hazards Earth Syst. Sci. 2012, 12, 2299-2309. [CrossRef]

40. Lindell, M.K.; Hwang, S.N. Households' Perceived Personal Risk and Responses in a Multihazard Environment. Risk Anal. 2008, 28, 539-556. [CrossRef]

41. Kalkstein, A.J.; Sheridan, S.C. The social impacts of the heat-health watch/warning system in Phoenix, Arizona: Assessing the perceived risk and response of the public. Int. J. Biometeorol. 2007, 52, 43-55. [CrossRef]

42. Röschel, L.; Graef, F.; Dietrich, O.; Schäfer, M.P.; Haase, D. Individual local farmers' perceptions of environmental change in Tanzania. Water 2018, 10, 525. [CrossRef]

43. Mulili, J.-P.; Duval, T.S. The PrE Model of Coping and Tornado Preparedness/ Moderating Effects of Responsibility. J. Appl. Soc. Psychol. 1997, 27, 1750-1766. [CrossRef]

44. Romero-Lankao, P.; Qin, H.; Dickinson, K. Urban vulnerability to temperature-related hazards: A meta-analysis and meta-knowledge approach. Glob. Environ. Chang. 2012, 22, 670-683. [CrossRef]

45. Lutz, W.; Cuaresma, J.C.; Sanderson, W. The demography of educational attainment and economic growth. Science 2008, 319, 1047-1048. [CrossRef] [PubMed] 
46. Lutz, W.; Muttarak, R.; Striessnig, E. Universal education is key to enhanced climate adaptation. Science 2014, 346, 1061-1062. [CrossRef]

47. Mason, L.R. Household solid fuel use in the Philippines: An exploratory spatial and social analysis. Asia Pac. J. Soc. Work Dev. 2012, 22, 228-242. [CrossRef]

48. Rybski, D.; Spies, M.; Zhou, B.; Kropp, J.P. Summary of Research on Area-Specific Climate Change Scenarios for Cities in the Philippines; Potsdam-Institute for Climate Impact Research: Potsdam, Germany, 2013.

49. Statista. Philippines: Unemployment Rate from 1998 to 2018. 2018. Available online: https://www.statista.com/ statistics/578722/unemployment-rate-in-philippines (accessed on 28 September 2019).

50. Mayring, P. Qualitative Inhaltsanalyse. Grundlagen und Techniken; 12. Auflage; Beltz: Weinheim, Germany, 2015.

51. Mayring, P. Qualitative content analysis: Theoretical background and procedures. In Approaches to Qualitative Research in Mathematics Education; Springer: Dordrecht, The Netherlands, 2015; pp. 365-380.

52. Bryman, A.; Cramer, D. Quantitative Data Analysis for Social Scientists; Routledge: London, UK, 1994.

53. Perez, A.M.C.; Blanco, A.C. Combination of MODIS Vegetation Indices, GRACE Terrestrial Water Storage Changes, and In-Situ Measurements for Drought Assessment in Cagayan River Basin, Philippines. J. Nat. Resour. Dev. 2017, 7, 45-55. [CrossRef]

54. Perez, G.J.; Macapagal, M.; Olivares, R.; Macapagal, E.M.; Comiso, J.C. Forecasting and Monitoring Agricultural Drought in the Philippines. Int. Arch. Photogramm. Remote Sens. Spat. Inf. Sci. 2016, 41, 1263-1269. [CrossRef]

55. Vicente-Serrano, S.M.; Beguería, S.; López-Moreno, J.I. A Multiscalar Drought Index Sensitive to Global Warming: The Standardized Precipitation Evapotranspiration Index. J. Clim. 2010, 23, 1696-1718. [CrossRef]

56. Cohen, J. A power primer. Psychol. Bull. 1992, 112, 155. [CrossRef]

57. Wilson, R.S.; Herziger, A.; Hamilton, M.; Brooks, J.S. From incremental to transformative adaptation in individual responses to climate-exacerbated hazards. Nat. Clim. Chang. 2020, 10, 200-208. [CrossRef]

58. Henrich, J.; Heine, S.J.; Norenzayan, A. Most people are not WEIRD. Nature 2010, 466, 29. [CrossRef] [PubMed]

59. The World Bank Individuals Using the Internet (\% of Population)—Philippines. Available online: https://data. worldbank.org/indicator/IT.NET.USER.ZS?end=2017\&locations=PH\&start=2011\&view =chart (accessed on 1 May 2020).

60. Martin-Shields, C.P. When information becomes action: Drivers of individuals' trust in broadcast versus peer-to-peer information in disaster response. Disasters 2019, 43, 612-633. [CrossRef] [PubMed]

61. Moser, S.C. Reflections on climate change communication research and practice in the second decade of the 21st century: What more is there to say? Wiley Interdiscip. Rev. Clim. Chang. 2016, 7, 345-369. [CrossRef]

62. De Leon, E.; Pittock, J. Integrating climate change adaptation and climate-related disaster risk-reduction policy in developing countries: A case study in the Philippines. Clim. Dev. 2017, 9, 471-478. [CrossRef]

63. Kuhlicke, C.; Seebauer, S.; Hudson, P.; Begg, C.; Bubeck, P.; Dittmer, C.; Grothmann, T.; Heidenreich, A.; Kreibich, H.; Lorenz, D.F. The behavioral turn in flood risk management, its assumptions and potential implications. Wiley Interdiscip. Rev. Water 2020, 7, e1418. [CrossRef]

64. Francisco, H.A.; Predo, C.D.; Manasboonphempool, A.; Tran, P.; Jarungrattanapong, R. Determinants of household decisions on adaptation to extreme climate events in Southeast Asia. EEPSEA research report series/IDRC. In Regional Office for Southeast and East Asia, Economy and Environment Program for Southeast Asia; EEPSEA: Laguna, Philippines, 2011.

65. Amundsen, H.; Berglund, F.; Westskog, H. Overcoming barriers to climate change adaptation-A question of multilevel governance? Environ. Plan. C Gov. Policy 2010, 28, 276-289. [CrossRef]

66. Adger, W.N.; Agrawal, S.; Mirza, M.M.W.; Conde, C.; O’brien, K.L.; Pulhin, J.; Pulwarty, R.; Smit, B.; Takahashi, K. Assessment of Adaptation Practices, Options, Constraints and Capacity; Cambridge University Press: Cambridge, UK, 2007.

67. Binh, P.T.; Zhu, X.; Groeneveld, R.A.; van Ierland, E.C. Risk communication, women's participation and flood mitigation in Vietnam: An experimental study. Land Use Policy 2020, 104436. [CrossRef]

68. Ngo, C.C.; Poortvliet, P.M.; Feindt, P.H. Drivers of flood and climate change risk perceptions and intention to adapt: An explorative survey in coastal and delta Vietnam. J. Risk Res. 2020, 23, 424-446. [CrossRef]

69. Tversky, A.; Kahnemann, D. Availability: A heuristic for judging frequency and probability. Cogn. Psychol. 1973, 2, 207-232. [CrossRef]

70. Evans, S. Journalistic Norms, Cultural Values, and Coverage of Climate Change in the Philippines. Environ. Commun. 2016, 10, 492-507. [CrossRef] 
71. Fritsche, I.; Barth, M.; Jugert, P.; Masson, T.; Reese, G. A social identity model of pro-environmental action (SIMPEA). Psychol. Rev. 2018, 125, 245-269. [CrossRef] [PubMed]

72. Kousky, C. Disasters as learning experiences or disasters as policy opportunities? Examining flood insurance purchases after hurricanes. Risk Anal. 2017, 37, 517-530. [CrossRef] [PubMed]

73. Eisenack, K.; Moser, S.C.; Hoffmann, E.; Klein, R.J.T.; Oberlack, C.; Pechan, A.; Rotter, M.; Termeer, C.J.A.M. Explaining and overcoming barriers to climate change adaptation. Nat. Clim. Chang. 2014, 4, 867-872. [CrossRef]

74. Kreibich, H.; Christenberger, S.; Schwarze, R. Economic motivation of households to undertake private precautionary measures against floods. Nat. Hazards Earth Syst. Sci. 2011, 11, 309-321. [CrossRef]

75. van Valkengoed, A.M.; Steg, L. Climate change adaptation by individuals and households: A psychological perspective. In Global Commission on Adaptation Background Paper; University of Groningen: Groningen, The Netherlands, 2019; Available online: https://cdn.gca.org/assets/2019-12/ ClimateChangeAdaptationByIndvsAndHouseholds.pdf (accessed on 15 July 2020).

(C) 2020 by the authors. Licensee MDPI, Basel, Switzerland. This article is an open access article distributed under the terms and conditions of the Creative Commons Attribution (CC BY) license (http://creativecommons.org/licenses/by/4.0/). 